\title{
Discovery of DB18, a potent inhibitor of CLK kinases with a high selectivity against DYRK1A kinase.
}

\author{
Dabbugoddu Brahmaiaha, ${ }^{a}$, Anagani Kanaka Durga Bhavani ${ }^{*}$, Pasula Aparna ${ }^{\mathrm{b}}$, Nangunoori Sampath \\ Kumar a, Hélène Solhi ${ }^{d}$, Rémy Le Guevel ${ }^{d}$, Blandine Baratte e,f, Sandrine Ruchaud ${ }^{f}$, Stéphane Bach e,f, \\ Surender Singh Jadav ${ }^{g}$, Chada Raji Reddy ${ }^{g}$, Thierry Roisnel ${ }^{h}$, Paul Mosset ${ }^{h}$, Nicolas Levoin ${ }^{{ }^{*}}$, and \\ René Grée ${ }^{h^{*}}$ \\ a. Chemveda Life Sciences India Pvt. Ltd., \#B-11/1, IDA Uppal, Hyderabad-500039, Telangana, India \\ b. Jawaharlal Nehru Technological University Hyderabad, Kukatpally, Hyderabad-500 085, Telangana, India \\ c. Department of Chemistry, Osmania University, Hyderabad 500007, Telangana, India \\ d. Univ Rennes, Plateform ImPACcell, BIOSIT, F-35000 Rennes, France. \\ e. Sorbonne Université, CNRS, FR 2424, Plateforme de criblage KISSf (Kinase Inhibitor Specialized Screening facility), Station Biologique de Roscoff, CS \\ 90074, 29688 Roscoff Cedex, France. \\ f. Sorbonne Université, CNRS, UMR 8227, Integrative Biology of Marine Models Laboratory (LBI2M), Station Biologique de Roscoff, CS 90074,29688 \\ Roscoff Cedex, France. \\ g. CSIR-Indian Institute of Chemical Technology, Uppal Road, Tarnaka, Hyderabad 500007, TS, India. \\ h. Univ Rennes, CNRS, ISCR (Institut des Sciences Chimiques de Rennes), UMR 6226, F-35000 Rennes, France. \\ i. Bioprojet-Biotech, 4 rue du Chesnay Beauregard, BP 96205, 35762 Saint Grégoire, France.
}

Keywords: Kinases • Quinazolines • Cancer • Triazoles • Molecular modelling •

\begin{abstract}
We describe in this paper the synthesis of a novel series of anilino-2-quinazoline derivatives. These compounds have been screened against a panel of eight mammalian kinases and in parallel they were tested for cytotoxicity on a representative panel of seven cancer cell lines. One of them (DB18) has been found to be a very potent inhibitor of human "CDC2-like kinases" CLK1, CLK2 and CLK4, with $\mathrm{IC}_{50}$ values in the 10-30 nM range. Interestingly, this molecule is inactive at $100 \mu \mathrm{M}$ on the closely related "dualspecificity tyrosine-regulated kinase 1A" (DYRK1A). Extensive molecular simulation studies have been performed on the relevant kinases to explain the strong affinity of this molecule on CLKs, as well as its selectivity against DYRK1A.
\end{abstract}

\section{Introduction}

One of the hallmarks of cancer is the deregulation of signaling pathways. ${ }^{1}$ These pathways are under the control of multiple protein kinases whose inhibition has emerged as a very successful topic in recent years. ${ }^{2}$ To date, 59 kinase inhibitors ${ }^{2 b}$ have been already approved by the US Food and Drug Administration (FDA) for therapeutic uses, mostly in oncology. ${ }^{3-4}$ Alternative splicing of RNA is the essential process by which higher eukaryote's proteome increased in diversity, gaining in cellular and functional complexity. However, this splicing process can be pathologically disrupted and promote the development and progression of cancer. ${ }^{5-7}$ These alterations include mutations affecting the specific splicing of cancer-associated genes or the splicing process itself. ${ }^{8}$ The alternative splicing process is carried out by the spliceosome and is further coordinated by multiple splicing factors, such as the serine-arginine rich protein family (SR proteins). ${ }^{9-10} \mathrm{SR}$ proteins are themselves regulated through phosphorylation by multiple kinases, called splicing kinases, such as CDC2-like kinases (CLKs), the serine-arginine protein kinases (SRPKs), pre-mRNA splicing 4 kinase (PRP4K/PRPF4B) and Topoisomerase I.11-15 Phosphorylation controls their nuclear localization and distribution within nuclear domains, regulating the splicing process. ${ }^{16-17}$ Splicing kinases are implicated in the tumorigenesis process where they are often dysregulated, making them interesting drug targets. ${ }^{18-19}$

CLKs are dual-specificity kinases present as four isoforms in mammals, CLK1 (Clk/Sty), CLK2-4.20-21 This, evolutionary conserved family, share a conserved C-terminus catalytic domain responsible for the autophosphorylation of their N-terminus RS-rich domain which, in turn, regulates their activity. CLKs phosphorylate SR proteins with different, or partially overlapping, substrates specificity. ${ }^{20}$ Due to the utmost involvement of alternative splicing in biological and cellular machinery, and the contribution of the CLKs in these pathways, ${ }^{22}$ CLK inhibitors are seen as very promising targets. Some have been tested in preclinical studies targeting different diseases, such as Duchenne muscular dystrophy, ${ }^{23}$ but most of the hope lies on cancer. For example, TG003 has demonstrated positive results in the case of gastric cancer, ${ }^{24} \mathrm{~T}-025$ is promising for MYC-driven breast cancer, ${ }^{25}$ and other series towards triple negative breast cancer. ${ }^{26}$ Very recently, SM08502 demonstrated antitumor activity in gastrointestinal cancer models. ${ }^{27}$ Unfortunately, 
the kinase domain similarity between CLKs and DYRKs led to inhibitor cross reactivity, ${ }^{28-32}$ rendering difficult the deciphering of precise biological functions of both enzyme families and this low selectivity could also undermine the clinical potential of these inhibitors. Although a few selective inhibitors have been reported recently, ${ }^{33-34}$ more selective drugs are awaited, as secondgeneration molecules.

Quinazoline is an important heterocycle in the core of various kinase inhibitors, such as Gefitinib (Iressa $\left.{ }^{8}\right)$, Vandetanib (Caprelsa 8 ), Afatinib (Giotrif $\AA$ ), Erlotinib (Tarceva $®)$, Canertinib, and Dacomitinib (Vizimpro®) which are drugs already in use for the treatment of cancers. ${ }^{35-36}$ However, in all these molecules an anilino group is linked to the heterocycle in position 4 . In the kinase inhibition area, only few examples of quinazolines with an amino group in position 2 and $\mathrm{H}$ in position 4 have been reported to date, ${ }^{37}$ with two molecules acting as inhibitors of the ASK1 kinase. ${ }^{37 f}$ Therefore, in order to explore in more depth the chemical space around this scaffold, we considered the introduction of different substitution patterns in position 2, through an heteroatom $\mathbf{X}$ (molecules $\boldsymbol{A}$, Figure 1).

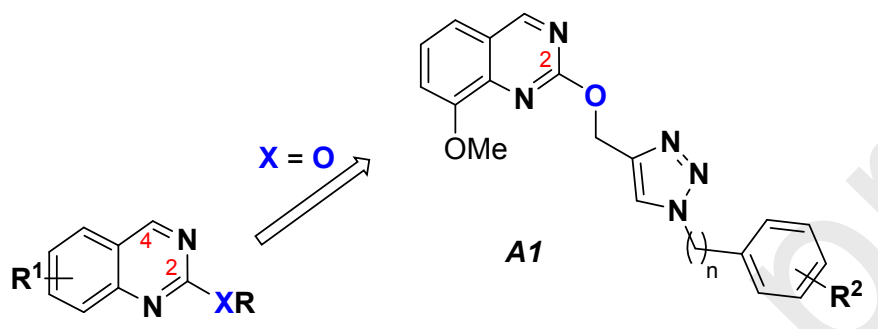

$\boldsymbol{A}$

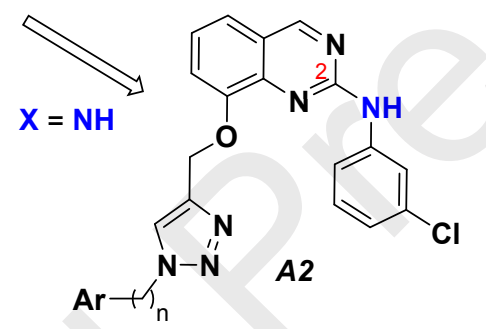

Figure 1. Design of target molecules $\boldsymbol{A 2}$.

We already described exploration of a series of molecules $(\boldsymbol{A 1})$ where $\mathbf{X}=\mathbf{0} .{ }^{38}$ On the other hand, preliminary in silico screening have established that 2-anilino quinazoline could be a promising scaffold for the interaction of type $\boldsymbol{A 2}$ molecules $(\mathbf{X}=\mathbf{N H})$ with the binding pocket of the CLK kinases. Therefore we selected to focus, in a first step, on the modulation of the "upper part" of these molecules with modifications around the substituted triazole moiety. In the current work, we report the synthesis and biological evaluation (kinase inhibition and cytotoxicity) of a focused library of such derivatives. We will demonstrate that one of them (DB18) is a very potent and selective inhibitor of the «CDC2-like Kinases » (CLKs), in particular CLK1, CLK2 and CLK4, that does not inhibit the "dual-specificity tyrosine-regulated kinase 1A » (DYRK1A). Extensive molecular modelling studies have been performed to rationalize the activity of this molecule on the CLKs kinases.

\section{Results and Discussion}

\section{Synthetic procedures}

Few methods have been reported for the preparation of 2-aminoquinazolines and further, most of the heterocycles prepared by these routes have also aryl groups in position 4. ${ }^{39}$ The synthesis of our target molecules (Scheme 1) starts from the known 2-chloro-8methoxyquinazoline $1 .{ }^{38}$ Reaction of 1 with meta-chloroaniline 2 in the presence of a palladium catalyst gave the 2-substituted anilinoquinazoline $\mathbf{3}$ in fair yield. The 8-hydroxyquinazoline $\mathbf{4}$, obtained from $\mathbf{3}$ by the demethylation of methoxy group in the presence of $\mathrm{BBr}_{3}$, reacted with propargyl bromide in the presence of 3 equivalents of potassium carbonate in acetone under reflux for $8 \mathrm{~h}$ to give the key intermediate $\mathbf{5}$. The presence of the propargyl group in $\mathbf{5}$ was evidenced by the presence of a doublet at $\delta 5.03$ and a triplet 
at $\delta 3.65$ in its ${ }^{1} \mathrm{H}$-NMR spectrum.

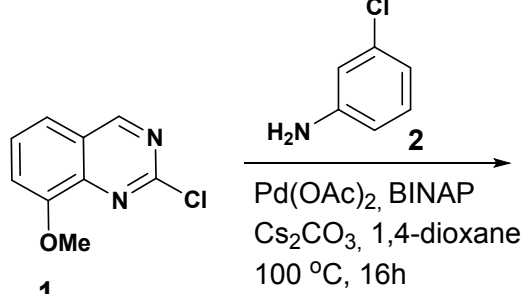

$58 \%$<smiles>COc1cccc2cnc(Nc3cccc(Cl)c3)nc12</smiles>

Propargyl bromide

reflux, $8 \mathrm{~h}$

$65 \%$

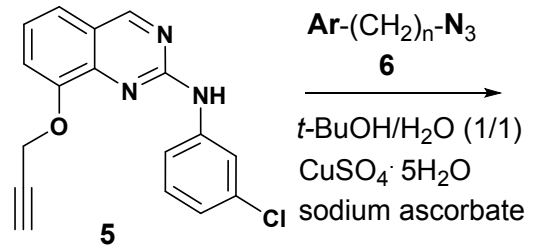

Ar groups and yields in Table 1

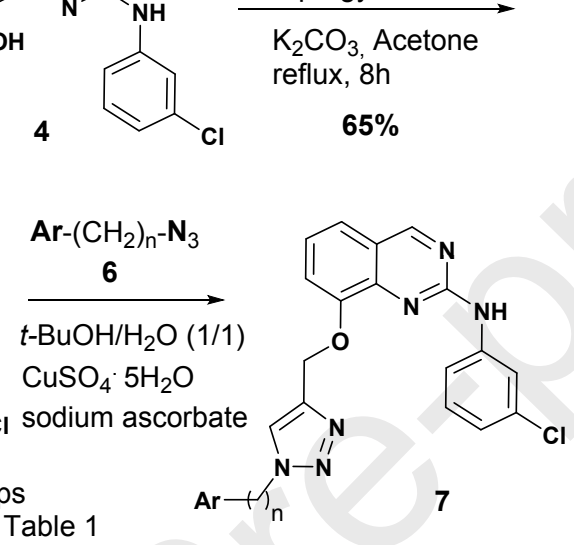

Scheme 1. Synthesis of the targeted anilino-2-quinazolines 7

The ${ }^{13} \mathrm{C}$-NMR spectrum also confirmed the presence of a O-propargyl group in $\mathbf{5}$ by showing the carbon peaks at $\delta 56.46,78.91$ and 78.58. Then, the target molecules 7 were obtained in fair to good yields, using click reaction ${ }^{40}$ between the alkyne 5 and the aryl/aralkyl azides 6 (Table 1).

Table 1. Synthesis of our target molecules 7.

\begin{tabular}{|c|c|c|c|c|}
\hline Entry & $\mathrm{n}$ & $\mathrm{Ar}$ & Molecule & Yield (\%) \\
\hline 1 & 0 & $-4-\mathrm{Cl}-\mathrm{C}_{6} \mathrm{H}_{4}$ & $7 a$ & 68 \\
\hline 2 & 0 & $-4-\mathrm{Br}-\mathrm{C}_{6} \mathrm{H}_{4}$ & $7 b$ & 64 \\
\hline 3 & 0 & $-4-\mathrm{OMe}-\mathrm{C}_{6} \mathrm{H}_{4}$ & 7c & 74 \\
\hline 4 & 0 & $-4-\mathrm{NO}_{2}-\mathrm{C}_{6} \mathrm{H}_{4}$ & $7 d$ & 60 \\
\hline 5 & 0 & $-2-\mathrm{OMe}-\mathrm{C}_{6} \mathrm{H}_{4}$ & $7 e$ & 70 \\
\hline 6 & 0 & $-3-\mathrm{OMe}-\mathrm{C}_{6} \mathrm{H}_{4}$ & $7 f$ & 78 \\
\hline 7 & 0 & 3,5-diCl- $\mathrm{C}_{6} \mathrm{H}_{3}$ & $7 g$ & 69 \\
\hline 8 & 0 & $-2-\mathrm{NO}_{2}-4-\mathrm{Me}-\mathrm{C}_{6} \mathrm{H}_{3}$ & 7h (DB18) & 64 \\
\hline 9 & 1 & $-4-\mathrm{NO}_{2}-\mathrm{C}_{6} \mathrm{H}_{4}$ & $7 i$ & 66 \\
\hline 10 & 1 & $-2,6 \mathrm{diCl}-\mathrm{C}_{6} \mathrm{H}_{3}$ & $7 \mathbf{j}$ & 72 \\
\hline
\end{tabular}




$\begin{array}{ccccc}11 & 1 & -\mathrm{C}_{6} \mathrm{H}_{5} & \mathbf{7 k} & 70 \\ 12 & 0 & -3-\mathrm{NO}_{2}-4-\mathrm{Me}_{-}-\mathrm{C}_{6} \mathrm{H}_{3} & 71 & 52\end{array}$

All compounds of this chemical library have spectral and analytical data fully consistent with the proposed structures (see Experimental Section and Supplementary Information). Further, in the case of $\mathbf{7 h}$, the structure was confirmed by $\mathrm{X}$-Ray analysis (Figure 2). 41

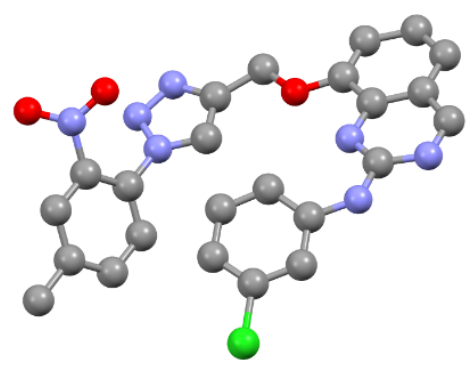

Figure 2. Structure of quinazoline $7 \mathrm{~h}(D B 18)$ established by X-Ray analysis.

\section{Biological studies}

\section{Kinase inhibition}

Our molecules contain a quinazoline scaffold, which has been often highlighted in kinase inhibition, ${ }^{[35-36]}$ therefore we used a short panel of kinases to perform a primary evaluation of their bioactivity. Eight disease-related serine/threonine protein kinases were tested including cyclin-dependent kinases (CDK5/p25, CDK9/cyclinT), proviral integration site for Moloney murine leukemia virus kinase (PIM1), glycogen synthase kinase-3 beta (GSK3ß), CDC Like Kinase 1 (CLK1), dual specificity tyrosine phosphorylation regulated kinase $1 A(D Y R K 1 A)$, casein kinase $1 \varepsilon(C K 1 \varepsilon)$ and the mitotic protein kinase haspin. The results are reported in Table 2 . An interesting specificity towards CLK1 was observed with these series. Several compounds such as $\mathbf{7 d}, \mathbf{7 e}, \mathbf{7 f}, \mathbf{7 h}, \mathbf{7 i}, \mathbf{7 j}$ and $\mathbf{7 I}$ used at $10 \mu \mathrm{M}$ displayed a residual CLK1 activity lower than $50 \%$ of the DMSO control $(26,26,27,11,39,48$ and $16 \%$ respectively). 
Table 2: Primary evaluation of the inhibition of quinazolines 7 against a short panel of mammalian kinases.[a]

\begin{tabular}{|c|c|c|c|c|c|c|c|c|}
\hline Compound & CDK5/ p25 & $\begin{array}{l}\text { CDK9/ } \\
\text { CyclinT }\end{array}$ & PIM1 & CLK1 & DYRK1A & HASPIN & GSK3 $\beta$ & CK1ع \\
\hline $7 a$ & 100 & 95 & 86 & 85 & 99 & 100 & 87 & 100 \\
\hline $7 b$ & 100 & 81 & 79 & 56 & 95 & 100 & 77 & 79 \\
\hline $7 c$ & 100 & 100 & 69 & 70 & 94 & 100 & 47 & 86 \\
\hline $7 d$ & 94 & 63 & 79 & 26 & 100 & 100 & 87 & 86 \\
\hline $7 e$ & 94 & 74 & 84 & 26 & 100 & 100 & 61 & 96 \\
\hline $7 f$ & 94 & 85 & 79 & 27 & 87 & 100 & 47 & 40 \\
\hline $7 g$ & 90 & 64 & 78 & 81 & 100 & 77 & 35 & 55 \\
\hline $7 \mathrm{~h}$ & 84 & 54 & 81 & 11 & 75 & 94 & 57 & 81 \\
\hline $7 i$ & 90 & 72 & 77 & 39 & 88 & 76 & 60 & 65 \\
\hline $7 j$ & 94 & 53 & 97 & 48 & 75 & 59 & 58 & 100 \\
\hline $7 k$ & 87 & 100 & 84 & 65 & 81 & 83 & 48 & 79 \\
\hline 71 & 40 & 25 & 45 & 16 & 74 & 44 & 14 & 41 \\
\hline
\end{tabular}

[a] Residual kinase activity was determined at $10 \mu \mathrm{M}$ concentration for each compound using $10 \mu \mathrm{M}$ ATP, and illustrated by a heat map from blue (100 \% kinase activity) to red ( $0 \%$ kinase activity). Kinases are from human origin (Homo sapiens) except CLK1 (from Mus musculus) and DYRK1A (from Rattus norvegicus).

Table 3. $I C_{50}$ data for the inhibition of human kinases CLK1-4 by the quinazoline $7 \mathrm{~h}$ (DB18). ${ }^{[\mathrm{a}]}$ 


\begin{tabular}{|c|c|}
\hline Kinase & $\mathrm{IC}_{50}(\mathrm{nM})$ \\
\hline CLK1 & 11 \\
\hline CLK2 & 27 \\
\hline CLK3 & 1280 \\
\hline CLK4 & 20 \\
\hline
\end{tabular}

[a] Kinase activities were measured by radiometric $\mathrm{Y}^{33} \mathrm{P}$-ATP assay (Eurofins, UK) using $15 \mu \mathrm{M}$ ATP. They were calculated from dose-response curves for which each point was measured in duplicate.

This specificity towards CLK1 was associated with a good selectivity when compared with the results obtained with all other kinases tested with the exception of 7I. Interestingly, the compounds showed very little to no effect on DYRK1A, a kinase for which CLK inhibitors often cross-react. ${ }^{28-32} I_{50}$ values were measured for the two best hits $7 \mathrm{~h}(D B 18)$ and $7 \mathrm{I}$ and found to be respectively 0.12 and $3 \mu \mathrm{M}$.

In order to extend the characterization of our best hit $\mathbf{7 h}$ (DB18), we tested its effects on the different human CLK family members (HsCLK1-4) (Table 3) and on various members of the DYRKs family of kinases, including human DYRK1A, DYRK1B and DYRK2 (see Supplementary Information Figure 1). In these experiments, we observed $\mathrm{IC}_{50}$ for $\mathrm{HsCLK}_{1}, 2$ and 4 of 11, 27 and $20 \mathrm{nM}$ respectively. However, DB18 activity was much lower with $H S C L K 3$ but such selectivity profile has already been reported for other inhibitors. ${ }^{23,28}$ Note here that the $\mathrm{IC}_{50}$ for the inhibition of human CLK1 by KH-CB19, a potent and highly specific inhibitor of the CLK1 and 4 kinases, was determined under the same experimental conditions. A similar $\mathrm{IC}_{50}$ value was obtained for $\mathrm{KH}-\mathrm{CB} 19$ against HsCLK1 (8 nM). Contrarily to the effect observed on CLKs, high doses of $7 \mathbf{h}$ (DB18) (up to $100 \mu \mathrm{M}$ ) does not inhibit the kinase activity of both rat and human DYRK1A, human DYRK1B and DYRK2 (Supplementary Information Figure 1). Therefore, the molecule 7h (DB18) appears as a novel and very promising hit towards inhibition of these CLK kinases, and the structure-activity relationships (SAR) for this series of molecules, will be discussed in the following section.

\section{Structural investigation by molecular simulations}

Our hit molecule 7h (DB18) was docked onto CLK1-4 crystal structures. The poses obtained by classical docking of induced-fit protocol were very similar, implying that the active site fitted very well to our inhibitor and did not require major rearrangement.

In agreement with its high affinity, DB18 formed many specific interactions with CLK1. Deeply buried in the cavity, the aminoquinazoline core stacked with F241 and underwent attractive van der Waals forces by V324 (Figure 3 and Supplementary Information Figure 1 for the cavity pose). It formed two hydrogen bonds with the backbone of L244, as seen for other 2-amino quinazolines. ${ }^{42}$ The chlorophenyl and L167 were in van der Waals contacts. The triazole was sandwiched between L295 and F172 and the nitrophenyl was subject to van der Waals interactions with E292. The nitro group formed hydrogen bond and electrostatic interactions with K290 and N293. It seems that the chlorine atom and the triazole formed an intramolecular interaction, such as halogen- $\pi$ bond. ${ }^{43-44}$
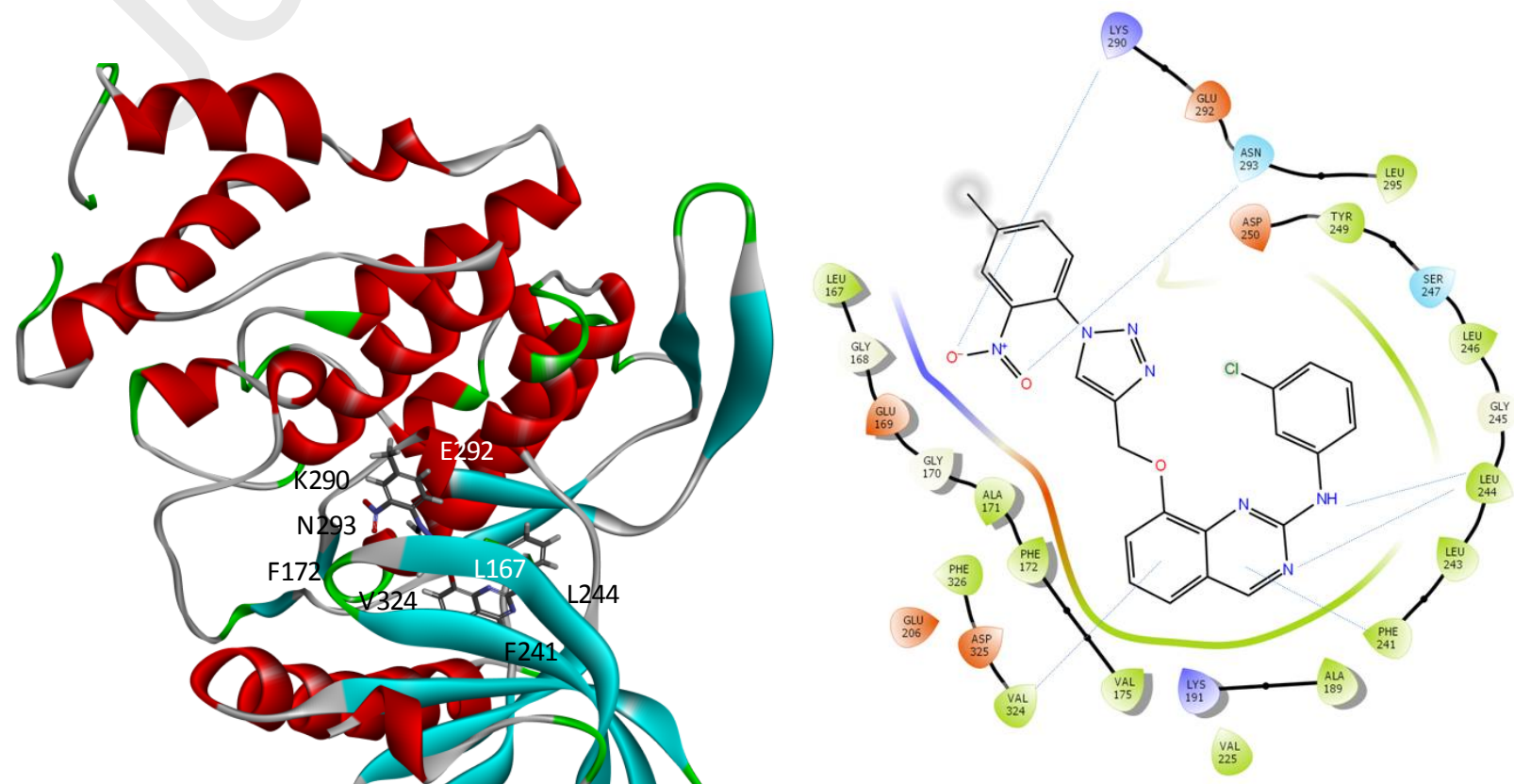
Figure 3. (left) $D B 18$ docked into the crystal structure of CLK1 with key interacting residues labeled; (right) 2D interaction diagram of $D B 18$ with CLK1.

These features were reminiscent of the ATP interactions with CLK1 and suggested that our molecules mimicked the ATP binding mode. Hence, the adenosine was buried in the cavity formed by F241, L295 and V176, as observed for the ANP:Ser/Thr kinase-1 of Plasmodium falciparum (PDB: 3LLT), or 5-iodo-tubercidin: CLK1 (PDB : 6G33). ${ }^{45}$ The 4-aminopyrimidine of ATP formed two hydrogen bonds with E242 and L244, and the triple phosphate interacted with K191, D332 and F172. Moreover, several of these crucial amino acids have been highlighted with other molecules, rigorously shown as ATP-competitive inhibitors. ${ }^{22,46}$

Electrostatic and hydrogen bonds are in line with observed SAR: the nitro group is very favorable, either in ortho (DB18) or meta (7I) position (N293 / K290), and to a lesser extend in para (7d, E292/Y249). Only hydrogen bonds are possible for the methoxy substituent $(\mathbf{7 e}, \mathbf{7 f})$, and the bringing closer to the phenyl of the hydrogen bond acceptor is less favorable, especially for the para position (7c).

Docking experiments suggested a similar binding mode for CLK2, CLK3 and CLK4 to CLK1. Given their high sequence similarity and conserved 3D structure, particularly within the active site, it is not unexpected that the above crucial interactions were also found between DB18 and CLKL2 to CLK4. Docked on CLK3, DB18 showed limited differences: it only lost van der Walls interactions with V324 (A467 in CLK3). This is an important loss but not sufficient to explain the measured drop of affinity. Indeed, Schröder et al. showed very recently that this position was partially responsible for the CLK1 selectivity of an inhibitor. ${ }^{47}$ In this study, CLK1 V324 mutation to $\mathrm{A} 324$, the corresponding amino acid in CLK3, decreased the affinity of an inhibitor for CLK1. Conversely, the CLK3 A319 mutation to V319 increased the affinity of the inhibitor for CLK3. But these effects were only partial and in fact, we found here that structural analysis of the whole enzymes is necessary to fully understand why DB18 is a weak inhibitor of CLK3.

Superimposition of CLK1 and CLK3 showed indeed that the inhibitor was more coated by the T166-A171 $\beta$-strand in CLK1 than in CLK3 (Figure 4), in agreement with previous studies showing that CLK3 adopted a more open conformation than CLK1.48,28 This probably resulted from a global induced-fit, involving the whole $\beta$-sheets G154 to K194 and E232 to L244, as a rigid body linked to the $\alpha$-helix D197-P218. In this region, CLK3 appears more rigid than CLK1, limiting the global motion needed to perfectly cover the inhibitor. Hence the $\alpha$-helix D197 to P218 is rigidly bond to the $\beta$-sheets domain through the loop N195V196, in addition to a salt bridge located in the middle of both secondary structures (K191/E206 in CLK1, K334/E349 in CLK3).

There are two other links between the $\alpha$-helix and $\beta$-strands, whose greater flexibility in CLK1 could explain the marked closing of the active site: (i) R347 / N375 hydrogen bond in CLK3, vs a more flexible salt bridge R204 / E232 in CLK1 (Figure 4), (ii) at the other end of the domain, two $\beta$-strands are strongly connected by m-stacking in CLK3 (W299/H324) which is absent from CLK1 (V156 / H181).
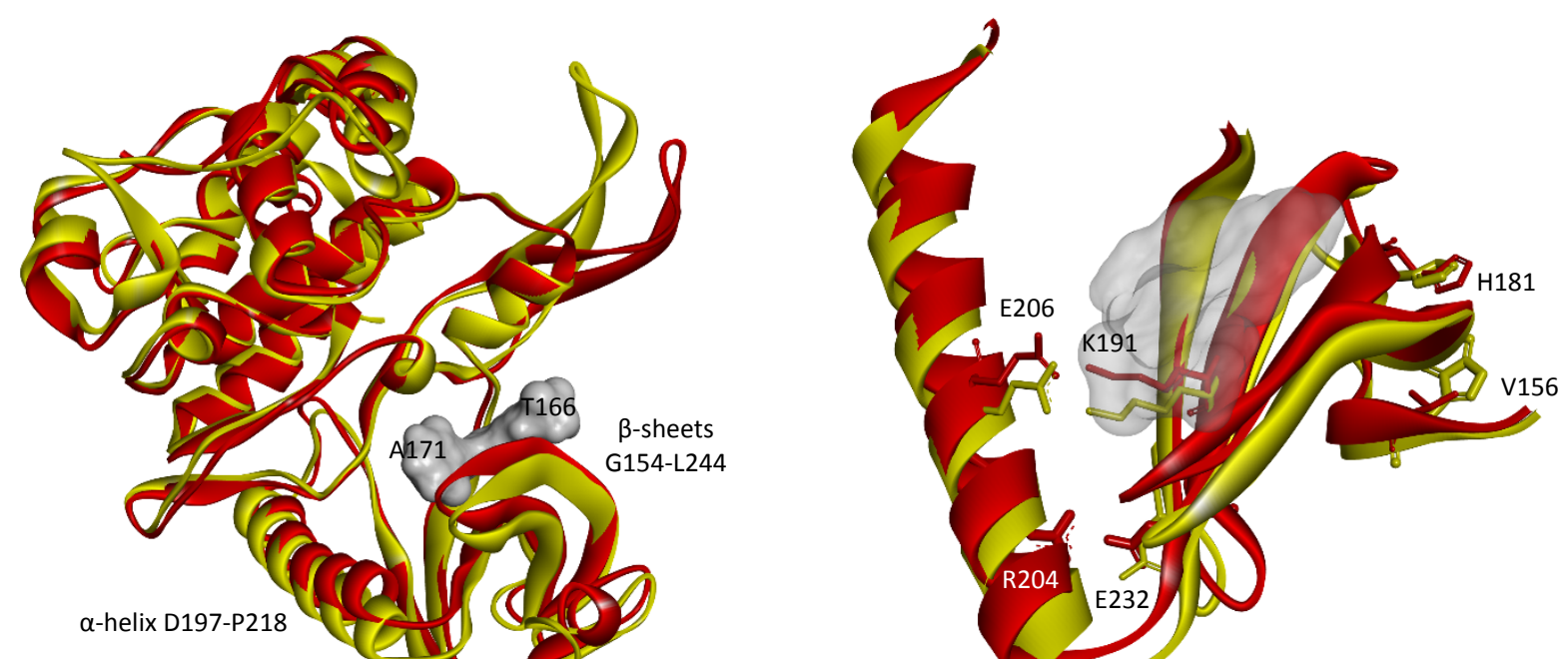
Figure 4. Superimposition of CLK1 (red) and CLK3 yellow). On the left, the whole structure is shown, with inhibitor in grey volume. On the right, important

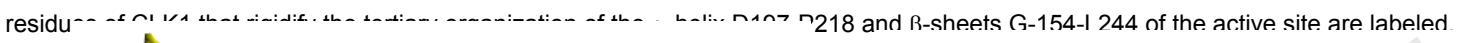
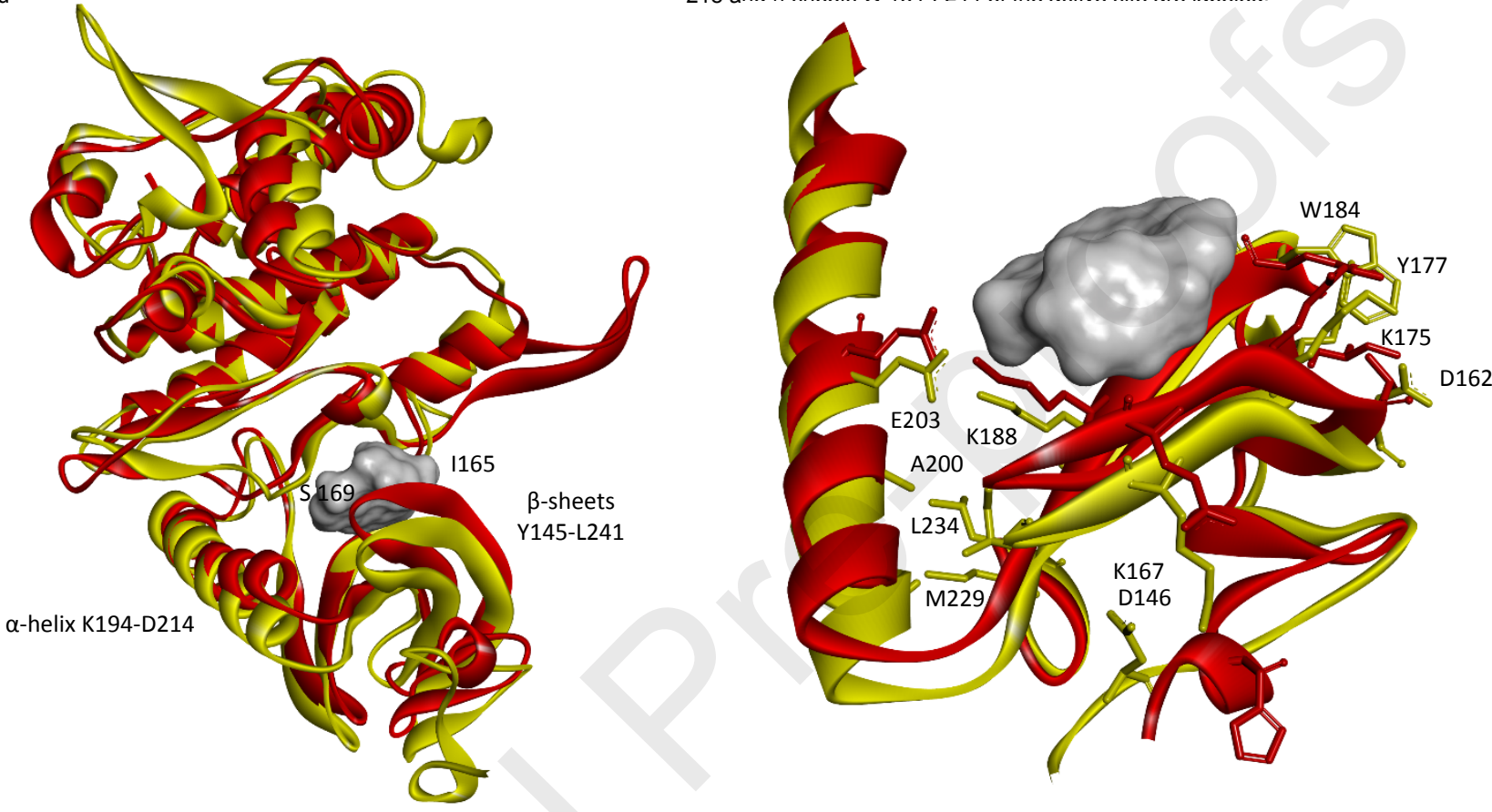

Figure 5. Superimposition of CLK1 (red) and DYRK1A (yellow). On the left, the whole structure is shown, with inhibitor in grey volume. On the right, important residues of DYRK1A that rigidify the tertiary organization of the $\alpha$-helix K194-D214 and $\beta$-sheets Y-145-L241 of the active site are labeled.

We then checked the stability of the docked pose, as well as the influence of the solvent via molecular dynamics. This experiment showed that neither ligand nor protein change a lot with time (RMSD $=2.4 \AA$ for Ca atoms, $1.6 \AA$ for DB18 (Supplementary Information Figures 2 and 3). A detailed analysis of ligand-protein contacts confirmed this observation, with F241, L244 and K191 permanently forming strong interactions with DB18. L295 and V324 van der Waals interactions were also highly conserved during the simulation (Supplementary Information Figure 4). Examination of the bond inhibitor showed also a notable steadiness, except the nitrophenyl group which rotated towards the chlorophenyl during the simulation, then stabilized in intramolecular contacts from 200 ns (Supplementary Information Figure 5). A conformational analysis of isolated DB18 showed that this rotation allowed a very low energy state, favored by intramolecular halogen bonds (Supplementary Information Figure 6). Taken together, these data suggested a competition between intramolecular contacts and protein hydrogen bond and/or electrostatic interactions involving K290 and N293.

Interestingly, the CLK1 / DYRK1A selectivity of DB18 seems to result from the same structural basis than CLK1 / CLK3, because there are few amino acid differences in their active site, apart A171, L246 and S247, which are replaced by S169, Y243 and N244 in DYRK1A (the latter mutation was also found in CLK3). Consequently, DYRK1A active site is slightly more hydrophilic than CLK1's. As observed for CLK3, the I165 to S169 $\beta$-strand of DYRK1A (corresponding to L167 to A171 in CLK1) is loosely packed to the inhibitor because of an increased rigidity of the former (Figure 5). This is mainly due to a cluster of van der Waals interactions 
between the $\alpha$-helix and $\beta$-sheet in DYRK1A (L197, A200, V204 / I190, L224, M229, L234, L236), salt bridges between $\beta$-strands (K167 / D146, K175 / D162) and m-stacking at the end of the $\beta$-sheet (Y177 / W184) which are absent in CLK1 (I179/H187).

In summary, molecular simulations and structural analyses of CLK1 to CLK4 and DYRK1A suggested that our inhibitors exploit the higher flexibility of CLK1 active site to form stronger interactions, and consequently to improve their selectivity.

\section{Cytotoxicity}

Cytotoxic activity of compounds and kinase inhibition are often related, ${ }^{49}$ therefore we performed in parallel a cytotoxicity screening of the twelve molecules 7a-7I, investigating seven representative cancer cell lines. The compounds effect on cell viability was evaluated on hepatocellular carcinoma Huh-7, colorectal adenocarcinoma CaCo2, colorectal carcinoma HCT-116, breast carcinoma MDA-MB 231, breast carcinoma MCF7, prostate carcinoma PC3 and lung carcinoid $\mathrm{NCl}-\mathrm{H} 727$ ). Human skin fibroblasts were used as reference for non-tumor cells and Roscovitine, Doxorubicin and Taxol as positive controls. After $48 \mathrm{~h}$ treatment with the compounds, cells were fixed and the nuclei were stained with Hoechst 33342, and counted using HCS technology (Supplementary Information, Table 1).

Compounds $\mathbf{7 a}, \mathbf{7 b}, \mathbf{7 e}, \mathbf{7 f}, \mathbf{7 g}, \mathbf{7 h}$ and $\mathbf{7 j}$ that induced a more than $30 \%$ decrease of cell population for at least one cell line were the most interesting, and were further investigated.

The determination of $\mathrm{IC}_{50}$ confirmed that $\mathbf{7 a}, \mathbf{7 b}, \mathbf{7 e}$ exhibited no effect on the normal human fibroblast at the highest concentration tested $(25 \mu \mathrm{M})$. At the same time, $7 \mathbf{b}$ demonstrated cytotoxicity on all cancer cell lines studied, while $7 \mathbf{e}$ appeared more selective towards three of them. On the other hand, $\mathbf{7 f}, \mathbf{7 g}, \mathbf{7 h}, \mathbf{7 j}$ exhibited cytotoxicity for both normal and cancerous cells (Table 4 ). It could be observed that compound 7e exhibited selective cytotoxicity for HuH7, PC3, MCF7 and 7h selective cytotoxicity for PC3 and MCF7. The compounds $7 \mathrm{e}$ and $7 \mathrm{~h}(\mathrm{DB} 18)$ were the more selective and the more potent with $\mathrm{IC}_{50}$ around 4-8 $\mu \mathrm{M}$.

Table 4. Cytotoxic studies ( $\mathrm{IC}_{50}$ determination) of selected quinazolines 7 . $^{\text {[a] }}$

\begin{tabular}{|c|c|c|c|c|c|c|c|c|}
\cline { 2 - 9 } \multicolumn{1}{c|}{} & HuH7 & CaCo-2 & $\begin{array}{c}\text { MDA- } \\
\text { MB231 }\end{array}$ & HCT116 & PC3 & NCl-H727 & MCF7 & Fibroblast \\
\hline DMSO & $>25$ & $>25$ & $>25$ & $>25$ & $>25$ & $>25$ & $>25$ & $>25$ \\
\hline Roscovitine & 14 & 17 & 15 & 9 & 10 & 28 & 9 & 6 \\
\hline Doxorubicine & 0.036 & 0.05 & 0.01 & 0.05 & 0.06 & 0 & 0.07 & 0.015 \\
\hline Taxol & 0.013 & 0.014 & 0.03 & 0.002 & 0.002 & 0.010 & 0.003 & 0.10 \\
\hline $\mathbf{7 a}$ & 24 & 24 & $>25$ & $>25$ & $>25$ & $>25$ & $>25$ & $>25$ \\
\hline $\mathbf{7 b}$ & 14 & 11 & 33 & 17 & 18 & 8 & 9 & $>25$ \\
\hline $\mathbf{7 e}$ & 7 & $>25$ & $>25$ & $>25$ & 8 & $>25$ & 6 & $>25$ \\
\hline $\mathbf{7 f}$ & 23 & 20 & 25 & 23 & 10 & $>25$ & 8 & 18 \\
\hline $\mathbf{7 g}$ & 7 & 8 & 9 & 8 & 8 & 7 & 5 & 8 \\
\hline $\mathbf{7 h}$ (DB18) & 25 & 37 & $>25$ & $>25$ & 7 & $>25$ & 4 & 21 \\
\hline $\mathbf{7 j}$ & 7 & 9 & 21 & 24 & 7 & 5 & 6 & 14 \\
\hline
\end{tabular}

[a] $I_{50}$ determination of quinazolines effects on seven representative tumor cell lines and normal Human fibroblast. IC $\mathrm{C}_{50}(\mu \mathrm{M})$ were calculated from dose-response curves after $48 \mathrm{~h}$ exposure (mean of triplicates).

\section{Conclusion}


In the present work, we reported the synthesis and biological evaluation of a series of novel anilino-2-quinazolines as kinase inhibitors, with selective cytotoxic activity towards cancer cells. One of them (DB18) has been discovered as a very potent and selective inhibitor of the "CDC2-like Kinases" (CLKs), in particular MmCLK1. These results have been confirmed on the human kinases with $\mathrm{IC}_{50}$ values in the 10-30 nM range for HsCLK1, HsCLK2 and HsCLK4. (DB18) was also shown to be remarkably inactive (even at $100 \mu \mathrm{M}$, the highest tested concentration) on various DYRK kinases, including rat and human DYRK1A, human DYRK1B and DYRK2. Extensive molecular modelling studies have been performed to rationalize the activity of this molecule on the CLKs kinases. This explains in particular the key roles of the anilino-2-quinazoline group, as well as for the aromatic nitro group on the chain. Based on such calculations, a proposal could also be made to explain the high selectivity of this hit molecule for CLK1 versus DYRK1A. Taken together, these results contribute to a better understanding and targeting of this, still underexplored, but very important family of kinases.

\section{Experimental Section}

\section{Chemical synthesis}

\section{General information}

All reactions were performed in heat gun-dried round-bottomed flasks under a dry argon or nitrogen atmosphere. Air and moisture-sensitive compounds were introduced via syringes or cannula, using standard inert atmosphere techniques. In addition, the gas stream was passed through glass cylinder filled with $\mathrm{P}_{2} \mathrm{O}_{5}$ to remove any traces of residual moisture. Reactions were monitored by thin layer chromatography (TLC) using E. Merck silica gel plates and components were visualized by illumination with short wavelength UV light and/or staining (Ninhydrin or basic $\mathrm{KMnO}_{4}$ ). All aldehydes were distilled right before use. All benzyl bromides and other reagents were used as they were received from commercial suppliers, unless otherwise noted. THF and $\mathrm{Et}_{2} \mathrm{O}$ were dried over sodium-benzophenone and distilled prior to use. Anhydrous $\mathrm{CH}_{2} \mathrm{Cl}_{2}$ was prepared by refluxing in the presence of $\mathrm{CaH}_{2}$ and distilled right before use unless otherwise noted.

${ }^{1} \mathrm{H}$ NMR spectra were recorded at 300 and $400 \mathrm{MHz}$, and ${ }^{13} \mathrm{C}$ NMR spectra at 75 and $100 \mathrm{MHz}$, in $\mathrm{CDCl}_{3}$ or DMSO-d $\mathrm{d}_{6}$ using TMS (tetramethylsilane) as an internal standard. Multiplicity was tabulated using standard abbreviations: $s$ for singlet, $d$ for doublet, dd for doublet of doublets, $t$ for triplet, $q$ for quadruplet, ddd for doublet of doublets of doublets and $\mathrm{m}$ for multiplet (br means broad). When necessary, in particular in order to have better accuracy on small coupling constants, resolution in ${ }^{1} \mathrm{H}$ NMR was enhanced using Traficante. All triazole compounds were purified by flash column chromatography on neutral alumina unless otherwise noted.

\section{Preparation of compound 3}

N-(3-Chlorophenyl)-8-methoxyquinazolin-2-amine (3):

To a stirred solution 2-chloro-8-methoxyquinazoline 1 (5 g, $25.7 \mathrm{mmol}$ ) and 3-chloroaniline 2 (3.6 g, $28.2 \mathrm{mmol})$ in 1,4-dioxane (150 mL) was added BINAP (1.58 g, $2.55 \mathrm{mmol}), \mathrm{Pd}(\mathrm{OAc})_{2}(286 \mathrm{mg}, 1.27 \mathrm{mmol})$ and $\mathrm{Cs}_{2} \mathrm{CO}_{3}(20 \mathrm{~g}, 61.6 \mathrm{mmol})$. Then, the reaction mixture was evacuated under vacuum, back filled with $\mathrm{N}_{2}$ atmosphere and heated to $100{ }^{\circ} \mathrm{C}$ for $16 \mathrm{~h}$. The reaction was monitored by TLC and after its completion, the reaction mixture was cooled to rt (room temperature) and then filtered through celite pad. The filtrate was concentrated and to this crude material, ice and water were added and after extraction with ethyl acetate $(2 \times 100 \mathrm{~mL})$, combined organic extracts were washed with brine $(50 \mathrm{~mL})$. Organic layer was dried over anhydrous sodium sulfate and concentrated to dryness. The crude resulting product was purified by chromatography on silica gel eluting with $5-20 \%$ ethyl acetate in hexane to give compound $3(4.26 \mathrm{~g}, 58 \%$ yield) as a yellow solid.

${ }^{1} \mathrm{H}$ NMR (400 MHz, DMSO-d 6 , $\delta$ ppm): 10.18 (br s, 1H), 9.32 (s, 1H), 8.45 (t, J = 2.0 Hz, 1H), 7.89 (ddd, J = 8.3, 2.1, $\left.0.9 \mathrm{~Hz}, 1 \mathrm{H}\right), 7.50(\mathrm{dd}, \mathrm{J}=7.0,2.3$ $\mathrm{Hz}, 1 \mathrm{H}), 7.37-7.30(\mathrm{~m}, 3 \mathrm{H}), 7.02$ (ddd, $J=7.9,2.1,0.9 \mathrm{~Hz}, 1 \mathrm{H}), 4.00$ (s, 3H); ${ }^{13} \mathrm{C}$ NMR (100 MHz, DMSO-d,$\left.\delta \mathrm{ppm}\right): 161.85,155.92,152.90,142.36$. $142.23,133.01,129.92,123.78,121.03,120.59,119.02,117.61,116.65,113.18,55.86$; Mass $(\mathrm{m} / \mathrm{z}): 285.2\left(\mathrm{M}^{+}\right)$.

\section{Preparation of compound 4}

2-((3-Chlorophenyl)amino)quinazolin-8-ol (4):

To a stirred solution of $\mathrm{N}$-(3-chlorophenyl)-8-methoxyquinazolin-2-amine $3(4 \mathrm{~g}, 14 \mathrm{mmol})$ in $\mathrm{CH}_{2} \mathrm{Cl}_{2}(160 \mathrm{~mL})$ was added $1 \mathrm{M} \mathrm{BBr} 3$ in $\mathrm{CH}_{2} \mathrm{Cl}_{2}(56 \mathrm{~mL})$ at $0{ }^{\circ} \mathrm{C}$, and the reaction mixture was stirred at $\mathrm{rt}$ for $18 \mathrm{~h}$. The reaction mixture was poured to a mixture of ice and water and stirred for $2 \mathrm{~h}$ at rt. The resulting solid was collected by filtration and washed with water $(2 \times 40 \mathrm{~mL})$. The obtained pale yellow solid was dried in a desicator to give compound $4(2.1 \mathrm{~g}, 55 \%$ yield) as a yellow solid.

${ }^{1} \mathrm{H}$ NMR (400 MHz, DMSO-d 6 , $\delta$ ppm): 10.04 (br s, 1H), $9.72(\mathrm{~s}, 1 \mathrm{H}), 9.28(\mathrm{~s}, 1 \mathrm{H}), 8.28(\mathrm{t}, \mathrm{J}=2.0 \mathrm{~Hz}, 1 \mathrm{H}), 8.00(\mathrm{ddd}, \mathrm{J}=8.3,2.1,0.9 \mathrm{~Hz}, 1 \mathrm{H}), 7.39(\mathrm{dd}$, 
$J=7.1,2.2 \mathrm{~Hz}, 1 \mathrm{H}), 7.33(\mathrm{t}, J=8.1 \mathrm{~Hz}, 1 \mathrm{H}), 7.27-7.20(\mathrm{~m}, 2 \mathrm{H}$ with $1 \mathrm{H}$ dd at $7.22 \mathrm{ppm}, J=7.6,2.2 \mathrm{~Hz}), 6.99(\mathrm{ddd}, J=7.9,2.1,0.9 \mathrm{~Hz}, 1 \mathrm{H}) ;{ }^{13} \mathrm{C} \mathrm{NMR}$ (100 MHz, DMSO-d 6 , $\delta$ ppm): 161.89, 155.52, 151.08, 142.18, 141.36, 132.91, 130.01, 124.06, 121.33, 120.57, 117.81, 117.51, 116.71, 116.67; Mass $(\mathrm{m} / \mathrm{z}): 272.2\left([\mathrm{M}+\mathrm{H}]^{+}\right)$.

\section{Preparation of compound 5}

N-(3-Chlorophenyl)-8-(prop-2-yn-1-yloxy)quinazolin-2-amine (5)

To a stirred solution of 2-((3-chlorophenyl)amino)quinazolin-8-ol 4 ( $3 \mathrm{~g}, 11.05 \mathrm{mmol})$ in acetone $(120 \mathrm{~mL})$, was added $\mathrm{K}_{2} \mathrm{CO}_{3}(4.58 \mathrm{~g}, 33.15 \mathrm{mmol})$ and propargyl bromide $(1.25 \mathrm{~mL}, 16.57 \mathrm{mmol})$ at rt. The reaction mixture was heated to reflux for $8 \mathrm{~h}$. It was then cooled to rt, filtered and concentrated to dryness. Purification by chromatography on silica gel (eluting with EtOAc in hexane) gave compound $\mathbf{5}(2.2 \mathrm{~g}, 60 \%$ yield) as a yellow solid.

${ }^{1} \mathrm{H}$ NMR $(400 \mathrm{MHz}$, DMSO-d 6 , $\delta$ ppm): 10.19 (br s, 1H), 9.34 (s, 1H), $8.45(\mathrm{t}, J=2.0 \mathrm{~Hz}, 1 \mathrm{H}$ ), 7.85 (ddd, $J=8.3,2.1,0.9 \mathrm{~Hz}, 1 \mathrm{H}$ ), $7.57(\mathrm{dd}, J=7.9,1.4$ $\mathrm{Hz}, 1 \mathrm{H}$ ), 7.41 (dd, $J=7.8,1.4 \mathrm{~Hz}, 1 \mathrm{H}), 7.35(\mathrm{t}, J=7.8 \mathrm{~Hz}, 1 \mathrm{H}), 7.33(\mathrm{t}, J=8.1 \mathrm{~Hz}, 1 \mathrm{H}), 7.02$ (ddd, $J=7.9,2.1,0.9 \mathrm{~Hz}, 1 \mathrm{H}), 5.03(\mathrm{~d}, J=2.4 \mathrm{~Hz}, 2 \mathrm{H}$ ), $3.65(\mathrm{t}, J=2.4 \mathrm{~Hz}, 1 \mathrm{H}) ;{ }^{13} \mathrm{C}$ NMR $(100 \mathrm{MHz}$, DMSO-d 6 , $\delta \mathrm{ppm}): 162.03,155.93,150.61,142.57,142.12,133.09,129.89,123.51,121.17,120.73$, $120.23,117.70,116.75,115.75,78.91,78.58,56.46 ;$ Mass $(\mathrm{m} / \mathrm{z}): 310.1\left([\mathrm{M}+\mathrm{H}]^{+}\right)$.

\section{General procedure for the preparation of compounds 7}

To the stirred solution of compounds $5\left(0.16 \mathrm{mmol}, 1.0\right.$ equiv.) and $\mathbf{6 a - I}$ [prepared using general protocol, ${ }^{12}(0.16 \mathrm{mmol}, 1$ equiv. $)$ in a $1: 1 \mathrm{mixture}$ of $t-$ butanol and water $(0.9 \mathrm{~mL})$ was added copper sulfate pentahydrate $(0.016 \mathrm{mmol}, 0.1$ equiv) and sodium ascorbate $(0.048 \mathrm{mmol}, 0.3$ equiv $)$ at rt. The resulting mixture was stirred for overnight. After completion of the reaction, it was diluted with a mixture of ethyl acetate and water (10 mL in a 1:1

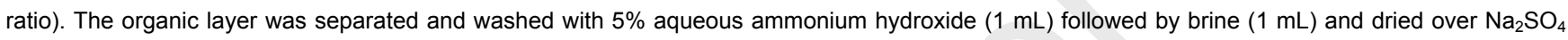
The solvents were evaporated under reduced pressure to give the crude product, which was purified by chromatography on silica gel affording target compounds $7 \mathrm{a}-\mathrm{I}$ ( $60-75 \%$ yield) as light yellow to brown solids.

\section{$\mathrm{N}$-(3-Chlorophenyl)-8-((1-(4-chlorophenyl)-1H-1,2,3-triazol-4-yl)methoxy)quinazolin-2-amine (7a)}

Reaction of compound 5 (50 mg, $0.16 \mathrm{mmol})$ with $6 \mathrm{a}(23.7 \mathrm{mg}, 0.16 \mathrm{mmol})$ gave $7 \mathrm{a}: 50.7 \mathrm{mg}, 68 \%$ yield; ${ }^{1} \mathrm{H}$ NMR $\left(300 \mathrm{MHz}, \mathrm{DMSO}-\mathrm{d}_{6}, \delta \mathrm{ppm}\right): 10.13$ (br s, 1H), $9.33(\mathrm{~s}, 1 \mathrm{H}), 9.09(\mathrm{~s}, 1 \mathrm{H}), 8.63(\mathrm{t}, \mathrm{J}=2.0 \mathrm{~Hz}, 1 \mathrm{H}$ ), 7.99 (half part of an AA'XX' system, 2H), 7.71 (half part of an AA'XX' system, 2H), 7.61$7.53(\mathrm{~m}, 3 \mathrm{H}), 7.38$ (dd, $J=8.2,7.6 \mathrm{~Hz}, 1 \mathrm{H}), 7.20(\mathrm{t}, J=8.1 \mathrm{~Hz}, 1 \mathrm{H}), 6.87$ (ddd, $J=7.9,2.1,0.9 \mathrm{~Hz}, 1 \mathrm{H}), 5.43(\mathrm{br} \mathrm{s}, 2 \mathrm{H}) ;{ }^{13} \mathrm{C} \mathrm{NMR}\left(100 \mathrm{MHz}, \mathrm{DMSO}-\mathrm{d}_{6}\right.$, $\delta$ ppm): 161.95, 155.79, 151.60, 143.79, 142.31, 142.02, 135.34, 133.03, 132.91, 129.84 (x 2), 129.60, 123.76, 123.16, 121.58 (x 2), 121.09, 120.49, 119.68, 117.50, 116.68, 114.78, 61.82; LC-MS: 463.4 [M+H]; HRMS (ESI, $\left.\mathrm{CH}_{3} \mathrm{OH} / \mathrm{CH}_{2} \mathrm{Cl}_{2}=9: 1\right) \mathrm{m} / \mathrm{z}$ calcd for $\mathrm{C}_{23} \mathrm{H}_{16}{ }^{35} \mathrm{Cl}_{2} \mathrm{~N}_{6} \mathrm{NaO}^{2} \mathrm{M}+\mathrm{Na}^{+}$: 485.06548, found: 485.0657 .

8-((1-(4-Bromophenyl)-1H-1,2,3-triazol-4-yl)methoxy)-N-(3-chlorophenyl)quinazolin-2-amine (7b)

Reaction of compounds 5 (50 mg, $0.16 \mathrm{mmol}$ ) with $\mathbf{6 b}(31.7 \mathrm{mg}, 0.16 \mathrm{mmol})$ gave $\mathbf{7 b}: 52 \mathrm{mg}, 64 \%$ yield; ${ }^{1} \mathrm{H}-\mathrm{NMR}\left(300 \mathrm{MHz}, \mathrm{DMSO}-\mathrm{d}_{6}, \delta \mathrm{ppm}\right): 10.13$ (br s, $1 \mathrm{H}$ ), $9.33(\mathrm{~s}, 1 \mathrm{H}), 9.10(\mathrm{~s}, 1 \mathrm{H}), 8.63(\mathrm{t}, \mathrm{J}=2.0 \mathrm{~Hz}, 1 \mathrm{H}$ ), 7.93 (half part of an AA'XX' system, 2H), 7.84 (half part of an AA'XX' system, 2H), 7.61$7.53(\mathrm{~m}, 3 \mathrm{H}), 7.38(\mathrm{dd}, J=8.1,7.6 \mathrm{~Hz}, 1 \mathrm{H}), 7.20(\mathrm{t}, J=8.1 \mathrm{~Hz}, 1 \mathrm{H}), 6.87$ (ddd, $J=7.9,2.1,0.9 \mathrm{~Hz}, 1 \mathrm{H}), 5.43(\mathrm{br} \mathrm{s}, 2 \mathrm{H}) ;{ }^{13} \mathrm{C} \mathrm{NMR}\left(75 \mathrm{MHz}, \mathrm{DMSO}^{-\mathrm{d}_{6}}\right.$, $\delta$ ppm): $161.94,155.77,151.59,143.78,142.27,142.01,135.73,133.03,132.76$ (x 2), 129.59, 123.76, 123.13, 121.78 (x 2), 121.28, 121.06, 120.48, 119.65, 117.48, 116.66, 114.69, 61.76; LC-MS: 507.3 [M+H]; HRMS (ESI, $\left.\mathrm{CH}_{3} \mathrm{OH} / \mathrm{CH}_{2} \mathrm{Cl}_{2}=9: 1\right) \mathrm{m} / \mathrm{z}$ calcd for $\left.\mathrm{C}_{23} \mathrm{H}_{16}{ }^{79} \mathrm{Br}^{35} \mathrm{CIN}_{6} \mathrm{NaO}^{2} \mathrm{M}+\mathrm{Na}\right]^{+}$ 529.01497, found: 529.0148 .

N-(3-Chlorophenyl)-8-((1-(4-methoxyphenyl)-1H-1,2,3-triazol-4-yl)methoxy)quinazolin-2-amine (7c)

Reaction of compounds 5 (50 mg, $0.16 \mathrm{mmol})$ with $6 \mathrm{c}(23.8 \mathrm{mg}, 0.16 \mathrm{mmol})$ gave $7 \mathrm{c}: 54.4 \mathrm{mg}, 74 \%$ yield; ${ }^{1} \mathrm{H} \mathrm{NMR}\left(300 \mathrm{MHz}, \mathrm{DMSO}-\mathrm{d}_{6}, \delta \mathrm{ppm}\right): 10.13$ (br s, 1H), $9.33(\mathrm{br} \mathrm{s}, 1 \mathrm{H}), 8.94(\mathrm{~s}, 1 \mathrm{H}), 8.61(\mathrm{t}, J=1.9 \mathrm{~Hz}, 1 \mathrm{H}$ ), 7.83 (half part of an AA'XX' system, 2H), 7.63-7.53 (m, 3H), 7.38 (dd after improving the resolution, $J=8.1,7.7 \mathrm{~Hz}, 1 \mathrm{H}$ ), $7.20(\mathrm{t}, J=8.1 \mathrm{~Hz}, 1 \mathrm{H}$ ), 7.16 (half part of an AA'XX' system, 2H), 6.88 (ddd, $J=7.9,2.1,0.9 \mathrm{~Hz}, 1 \mathrm{H}$ ), $5.41(\mathrm{br} \mathrm{s}$, 2H), 3.85 (s, 3H); ${ }^{13} \mathrm{C}$ NMR $(75 \mathrm{MHz}$, DMSO-d 6 , $\delta \mathrm{ppm}): 161.95,159.17,155.78,151.63,143.33,142.29,142.02,133.07,129.96,129.60,123.77$, 122.99, 121.54 (x 2), 121.07, 120.48, 119.60, 117.49, 116.64, 114.81 (x 2), 114.66, 61.87, 55.47; LC-MS: 459.4 [M+H]; HRMS (ESI, $\left.\mathrm{CH}_{3} \mathrm{OH} / \mathrm{CH}_{2} \mathrm{Cl}_{2}=9: 1\right) \mathrm{m} / \mathrm{z}$ calcd for $\mathrm{C}_{24} \mathrm{H}_{19}{ }^{35} \mathrm{CIN}_{6} \mathrm{NaO}_{2}[\mathrm{M}+\mathrm{Na}]^{+}: 481.11502$, found: 481.1148 , calcd for $\mathrm{C}_{24} \mathrm{H}_{19}{ }^{35} \mathrm{CIN}_{6} \mathrm{KO}_{2}[\mathrm{M}+\mathrm{K}]^{+}: 497.08896$, found: 497.0892.

\section{N-(3-Chlorophenyl)-8-((1-(4-nitrophenyl)-1H-1,2,3-triazol-4-yl)methoxy)quinazolin-2-amine (7d)}

Reaction of compounds 5 (50 mg, $0.16 \mathrm{mmol}$ ) with $\mathbf{6 d}\left(26.3 \mathrm{mg}, 0.16 \mathrm{mmol}\right.$ ) gave $7 \mathrm{~d}: 45.3 \mathrm{mg}, 60 \%$ yield; ${ }^{1} \mathrm{H} \mathrm{NMR}\left(300 \mathrm{MHz}, \mathrm{DMSO}-\mathrm{d}_{6}, \delta \mathrm{ppm}\right): 10.14$ (br s, $1 \mathrm{H}$ ), $9.34(\mathrm{~s}, 1 \mathrm{H}), 9.29(\mathrm{~s}, 1 \mathrm{H}), 8.64(\mathrm{t}, J=1.9 \mathrm{~Hz}, 1 \mathrm{H}$ ), 8.49 (half part of an AA'XX' system, 2H), 8.28 (half part of an AA'XX' system, 2H), 7.62$7.53(\mathrm{~m}, 3 \mathrm{H}), 7.39$ (dd after improving the resolution, $J=8.2,7.6 \mathrm{~Hz}, 1 \mathrm{H}), 7.20(\mathrm{t}, J=8.1 \mathrm{~Hz}, 1 \mathrm{H}$ ), 6.86 (ddd, $J=7.9,2.1,0.9 \mathrm{~Hz}, 1 \mathrm{H}), 5.46(\mathrm{br} \mathrm{s}, 2 \mathrm{H}$ ); ${ }^{13} \mathrm{C}$ NMR $\left(100 \mathrm{MHz}\right.$, DMSO- $\left.\mathrm{d}_{6}, \delta \mathrm{ppm}\right): 161.96,155.79,151.58,146.71,144.30,142.32,142.02,140.76,133.00,129.61,125.56$ (x 2), $123.76,123.61$, 121.10, 120.50, 120.47 (x 2), 119.77, 117.52, 116.71, 114.89, 61.74; LC-MS: 474.4 [M+H]; HRMS (ESI, $\left.\mathrm{CH}_{3} \mathrm{OH}_{\mathrm{CH}} \mathrm{Cl}_{2}=9: 1\right) \mathrm{m} / \mathrm{z}$ calcd for $\mathrm{C}_{23} \mathrm{H}_{16}{ }^{35} \mathrm{CIN}_{7} \mathrm{NaO}_{3}[\mathrm{M}+\mathrm{Na}]^{+}: 496.08954$, found: 496.0900 , calcd for $\mathrm{C}_{23} \mathrm{H}_{17}{ }^{35} \mathrm{CIN}_{7} \mathrm{O}_{3}[\mathrm{M}+\mathrm{H}]^{+}: 474.10759$, found: 474.1075 . 


\section{N-(3-Chlorophenyl)-8-((1-(2-methoxyphenyl)-1H-1,2,3-triazol-4-yl)methoxy)quinazolin-2-amine (7e)}

Reaction of compounds $5(50 \mathrm{mg}, 0.16 \mathrm{mmol})$ with 6 e $(23.9 \mathrm{mg}, 0.16 \mathrm{mmol})$ gave $7 \mathrm{e}: 51 \mathrm{mg}, 70 \%$ yield; ${ }^{1} \mathrm{H}$ NMR $\left(300 \mathrm{MHz}, \mathrm{DMSO}-\mathrm{d}_{6}, \delta \mathrm{ppm}\right): 10.14$ (br s, 1H), $9.34(\mathrm{br} \mathrm{s}, 1 \mathrm{H}), 8.66(\mathrm{~s}, 1 \mathrm{H}), 8.49(\mathrm{t}, J=2.0 \mathrm{~Hz}, 1 \mathrm{H}), 7.71$ (ddd, $J=8.3,2.1,0.9 \mathrm{~Hz}, 1 \mathrm{H}), 7.66(\mathrm{dd}, J=7.9,1.7 \mathrm{~Hz}, 1 \mathrm{H}), 7.61-7.52(\mathrm{~m}, 3 \mathrm{H}$ ), 7.39 (dd after improving the resolution, $J=8.1,7.7 \mathrm{~Hz}, 1 \mathrm{H}$ ), 7.34 (dd, $J=8.5,1.2 \mathrm{~Hz}, 1 \mathrm{H}), 7.20(\mathrm{t}, J=8.1 \mathrm{~Hz}, 1 \mathrm{H}), 7.18(\mathrm{td}, J=7.7,1.2 \mathrm{~Hz}, 1 \mathrm{H}), 6.90$ (ddd, $J=7.9,2.1,0.9 \mathrm{~Hz}, 1 \mathrm{H}$ ), 5.44 (br s, 2H), 3.84 (s, 3H); ${ }^{13} \mathrm{C}$ NMR (75 MHz, DMSO-d,$\delta$ ppm): 161.97, 155.84, 151.61, 151.37, 142.44, 142.38, 142.06, 133.01, 130.65, 129.66, 126.42, 125.52, 125.42, 123.77, 121.12, 120.85, 120.51, 119.67, 117.46, 116.68, 114.85, 112.94, 61.95, 55.98; LCMS: $459.4[\mathrm{M}+\mathrm{H}]$; HRMS (ESI, $\left.\mathrm{CH}_{3} \mathrm{OH} / \mathrm{CH}_{2} \mathrm{Cl}_{2}=9: 1\right) \mathrm{m} / \mathrm{z}$ calcd for $\mathrm{C}_{24} \mathrm{H}_{19}{ }^{35} \mathrm{CIN}_{6} \mathrm{NaO}_{2}$ [M+ Na] $]^{+}$: 481.11502, found: 481.1145, calcd for $\mathrm{C}_{24} \mathrm{H}_{19}{ }^{35} \mathrm{CIN}_{6} \mathrm{KO}_{2}[\mathrm{M}+\mathrm{K}]^{+}:$497.08896, found: 497.0888 .

N-(3-Chlorophenyl)-8-((1-(3-methoxyphenyl)-1H-1,2,3-triazol-4-yl)methoxy)quinazolin-2-amine (7f)

Reaction of compounds 5 (50 mg, $0.16 \mathrm{mmol})$ with $6 \mathrm{6f}(23.9 \mathrm{mg}, 0.16 \mathrm{mmol})$ gave $7 \mathrm{f}: 57 \mathrm{mg}, 78 \%$ yield; ${ }^{1} \mathrm{H}$ NMR $\left(300 \mathrm{MHz}, \mathrm{DMSO}-\mathrm{d}_{6}, \delta \mathrm{ppm}\right): 10.13$ (br s, 1H), 9.34 (very br s as an envelope from 9.26 to $9.41 \mathrm{ppm}, 1 \mathrm{H}$ ), $9.08(\mathrm{~s}, 1 \mathrm{H}), 8.62(\mathrm{br} \mathrm{t}, \mathrm{J}=1.9 \mathrm{~Hz}, 1 \mathrm{H}), 7.62-7.48(\mathrm{~m}, 6 \mathrm{H}), 7.39(\mathrm{dd}$ after improving the resolution, $J=8.1,7.6 \mathrm{~Hz}, 1 \mathrm{H}), 7.20(\mathrm{t}, J=8.1 \mathrm{~Hz}, 1 \mathrm{H}), 7.12-7.04(\mathrm{~m}, 1 \mathrm{H}), 6.87(\mathrm{ddd}, J=7.9,2.1,0.8 \mathrm{~Hz}, 1 \mathrm{H}), 5.43(\mathrm{br} \mathrm{s}, 2 \mathrm{H}), 3.87(\mathrm{~s}$, $3 \mathrm{H}) ;{ }^{13} \mathrm{C}$ NMR (100 MHz, DMSO-d 6 , $\left.\delta \mathrm{ppm}\right): 161.94,160.10,155.80,151.63,143.54,142.34,142.02,137.59,133.07,130.79,129.60,123.76,123.18$, 121.10, 120.49, 119.68, 117.52, 116.67, 114.81, 114.32, 111.90, 105.57, 61.90, 55.52; LC-MS: 459.4 [M+H]; HRMS $\left(\mathrm{ESI}_{1} \mathrm{CH}_{3} \mathrm{OH} / \mathrm{CH}_{2} \mathrm{Cl} 2=9: 1\right) \mathrm{m} / \mathrm{z}$ calcd for $\mathrm{C}_{24} \mathrm{H}_{19}{ }^{35} \mathrm{CIN}_{6} \mathrm{NaO}_{2}[\mathrm{M}+\mathrm{Na}]^{+}: 481.11502$, found: 481.1153 , calcd for $\mathrm{C}_{24} \mathrm{H}_{19}{ }^{35} \mathrm{CIN}_{6} \mathrm{KO}_{2}[\mathrm{M}+\mathrm{K}]^{+}: 497.08896$, found: 497.0890 .

\section{N-(3-Chlorophenyl)-8-((1-(3,5-dichlorophenyl)-1H-1,2,3-triazol-4-yl)methoxy)quinazolin-2-amine (7g)}

Reaction of compounds 5 (50 mg, $0.16 \mathrm{mmol})$ with $\mathbf{6 g}(30.1 \mathrm{mg}, 0.16 \mathrm{mmol})$ gave $\mathbf{7 g}: 54 \mathrm{mg}, 69 \%$ yield; ${ }^{1} \mathrm{H}$ NMR $\left(300 \mathrm{MHz}, \mathrm{DMSO}-\mathrm{d}_{6}, \delta \mathrm{ppm}\right): 10.14$ (br s, 1H), $9.34(\mathrm{br} \mathrm{s}, 1 \mathrm{H}), 9.20(\mathrm{~s}, 1 \mathrm{H}), 8.60(\mathrm{t}, J=2.0 \mathrm{~Hz}, 1 \mathrm{H}), 8.12(\mathrm{~d}, J=1.8 \mathrm{~Hz}, 2 \mathrm{H}), 7.79(\mathrm{t}, J=1.8 \mathrm{~Hz}, 1 \mathrm{H}), 7.61(\mathrm{ddd}, J=8.3,2.1,0.9 \mathrm{~Hz}, 1 \mathrm{H})$, $7.57(\mathrm{~d}, J=7.9 \mathrm{~Hz}, 2 \mathrm{H}$ ), 7.38 (dd after improving the resolution, $J=8.2,7.5 \mathrm{~Hz}, 1 \mathrm{H}), 7.22(\mathrm{t}, J=8.1 \mathrm{~Hz}, 1 \mathrm{H}$ ), 6.89 (ddd, $J=7.9,2.1,0.9 \mathrm{~Hz}, 1 \mathrm{H}), 5.45$ (br s, 2H); ${ }^{13} \mathrm{C}$ NMR (75 MHz, DMSO-d 6 , $\delta$ ppm): 161.97, 155.79, 151.53, 144.03, 142.30, 142.02, 138.10, 135.22 (x 2), 132.98, 129.65, 128.04, $123.75,123.43,121.09,120.52,119.77,118.51$ (x 2), 117.49, 116.71, 114.91, 61.79; LC-MS: 497.4 [M+H]; HRMS $\left(\mathrm{ESI}^{\mathrm{C}} \mathrm{CH} \mathrm{OH}_{3} \mathrm{CH} \mathrm{Cl}_{2}=9: 1\right) \mathrm{m} / \mathrm{z}$ calcd for $\mathrm{C}_{23} \mathrm{H}_{16}{ }^{35} \mathrm{Cl}_{3} \mathrm{~N}_{6} \mathrm{O}[\mathrm{M}+\mathrm{H}]^{+}: 497.04457$, found: 497.0445 , calcd for $\mathrm{C}_{23} \mathrm{H}_{15}{ }^{35} \mathrm{Cl}_{3} \mathrm{~N}_{6} \mathrm{NaO}[\mathrm{M}+\mathrm{Na}]^{+}$: 519.02651, found: 519.0265, calcd for $\mathrm{C}_{23} \mathrm{H}_{15}{ }^{35} \mathrm{Cl}_{3} \mathrm{~N}_{6} \mathrm{KO}[\mathrm{M}+\mathrm{K}]^{+}: 535.00045$, found: 535.0003

\section{N-(3-Chlorophenyl)-8-((1-(4-methyl-2-nitrophenyl)-1H-1,2,3-triazol-4-yl)methoxy)quinazolin-2-amine (7h)}

Reaction of compounds 5 (50 mg, $0.16 \mathrm{mmol})$ with $6 \mathrm{~h}(28.5 \mathrm{mg}, 0.16 \mathrm{mmol})$ gave $7 \mathrm{~h}: 49.8 \mathrm{mg}, 64 \%$ yield; ${ }^{1} \mathrm{H}$ NMR $\left(300 \mathrm{MHz}, \mathrm{DMSO}-\mathrm{d}_{6}, \delta \mathrm{ppm}\right): 10.14$ (br s, $1 \mathrm{H}), 9.34(\mathrm{~s}, 1 \mathrm{H}), 8.84(\mathrm{~s}, 1 \mathrm{H}), 8.44(\mathrm{t}, \mathrm{J}=2.0 \mathrm{~Hz}, 1 \mathrm{H}), 8.10-8.07(\mathrm{~m}, 1 \mathrm{H}), 7.82-7.75(\mathrm{~m}, 2 \mathrm{H}: 1 \mathrm{H}$ ddq at $7.80 \mathrm{ppm}, \mathrm{J}=8.1,1.8,0.6 \mathrm{~Hz}$ after improving the resolution and $1 \mathrm{H}$ ddd at $7.78 \mathrm{ppm}, J=8.2,2.1,0.9 \mathrm{~Hz}$ after improving the resolution), 7.74 (d with a strong roof effect, $J=8.1 \mathrm{~Hz}, 1 \mathrm{H}$ ), $7.57(\mathrm{~d}, J=8.0 \mathrm{~Hz}, 2 \mathrm{H}$ ), 7.38 (dd, $J=8.3,7.4 \mathrm{~Hz}, 1 \mathrm{H}$ ), $7.23(\mathrm{t}, J=8.1 \mathrm{~Hz}, 1 \mathrm{H}$ ), 6.91 (ddd, $J=7.9,2.1,0.9 \mathrm{~Hz}, 1 \mathrm{H}$ ), 5.47 (br s, $2 \mathrm{H}$ ), 2.52 (br s, t after improving the resolution, $J=0.6 \mathrm{~Hz}, 3 \mathrm{H}) ;{ }^{13} \mathrm{C}$ NMR $(100 \mathrm{MHz}$, DMSO-d $6 . \delta \mathrm{ppm}): 162.00,155.87,151.52,143.69,143.38,142.46,142.07,141.86$, 134.56, 132.95, 129.76, 126.92, 126.56, 125.74, 125.51, 123.73, 121.18, 120.56, 119.92, 117.55, 116.74, 115.35, 61.95, 20.33; LC-MS: 488.4 [M+H]; HRMS (ESI, $\mathrm{CH}_{3} \mathrm{OH} / \mathrm{CH}_{2} \mathrm{Cl}_{2}=9: 1$ ) $\mathrm{m} / \mathrm{z}$ calcd for $\mathrm{C}_{24} \mathrm{H}_{18}{ }^{35} \mathrm{CIN}_{7} \mathrm{NaO}_{3}[\mathrm{M}+\mathrm{Na}]^{+}: 510.10519$, found: 510.1054 , calcd for $\mathrm{C}_{24} \mathrm{H}_{18}{ }^{35} \mathrm{ClN}_{7} \mathrm{KO}_{3}\left[\mathrm{M}+\mathrm{K}^{+}\right.$: 526.07912, found: 526.0790 , calcd for $\mathrm{C}_{24} \mathrm{H}_{19}{ }^{35} \mathrm{CIN}_{7} \mathrm{O}_{3}[\mathrm{M}+\mathrm{H}]^{+}$: 488.12324, found: 488.1228 .

N-(3-Chlorophenyl)-8-((1-(4-nitrobenzyl)-1H-1,2,3-triazol-4-yl)methoxy)quinazolin-2-amine (7i)

Reaction of compounds 5 (50 mg, $0.16 \mathrm{mmol})$ with $6 \mathbf{i}(23.7 \mathrm{mg}, 0.16 \mathrm{mmol})$ gave $7 \mathrm{i}: 50.7 \mathrm{mg}, 66 \%$ yield; ${ }^{1} \mathrm{H}-\mathrm{NMR}\left(400 \mathrm{MHz}, \mathrm{DMSO}-\mathrm{d}_{6}, \delta \mathrm{ppm}\right): 10.13$ (br s, 1H), $9.32(\mathrm{~s}, 1 \mathrm{H}$ ), $8.43(\mathrm{~s}, 1 \mathrm{H}$ ), 8.37 (t, $J=1.9 \mathrm{~Hz}, 1 \mathrm{H}$ ), 8.24 (half part of an AA'XX' system, 2H), 7.79 (ddd, $J=8.3,2.0,0.9 \mathrm{~Hz}, 1 \mathrm{H}$ ), 7.57 (half part of an AA'XX' system, 2H), 7.55 (dd, $J=8.1,1.1 \mathrm{~Hz}, 1 \mathrm{H}), 7.52(\mathrm{dd}, J=7.9,1.2 \mathrm{~Hz}, 1 \mathrm{H}), 7.36(\mathrm{t}, J=7.9 \mathrm{~Hz}, 1 \mathrm{H}), 7.15(\mathrm{t}, J=8.1 \mathrm{~Hz}, 1 \mathrm{H}), 6.90(\mathrm{ddd}$, $J=7.9,2.1,0.8 \mathrm{~Hz}, 1 \mathrm{H}), 5.84(\mathrm{~s}, 2 \mathrm{H}), 5.38$ (s, 2H); ${ }^{13} \mathrm{C}$ NMR $\left(75 \mathrm{MHz}, \mathrm{DMSO}-\mathrm{d}_{6}, \delta \mathrm{ppm}\right): 161.96,155.81,151.54,147.15,143.32,143.01,142.45$, 142.07, 132.96, 129.72, 128.97 (x 2), 125.15, 123.81 (x 2), 123.72, 121.13, 120.48, 119.72, 117.55, 116.62, 115.15, 62.00, 51.84; LC-MS: 488.4 $[\mathrm{M}+\mathrm{H}]$; HRMS (ESI, $\left.\mathrm{CH}_{3} \mathrm{OH} / \mathrm{CH}_{2} \mathrm{Cl}_{2}=9: 1\right) \mathrm{m} / \mathrm{z}$ calcd for $\mathrm{C}_{24} \mathrm{H}_{18}{ }^{35} \mathrm{CIN}_{7} \mathrm{NaO}_{3}[\mathrm{M}+\mathrm{Na}]^{+}: 510.10519$, found: 510.1054 , calcd for $\mathrm{C}_{24} \mathrm{H}_{18}{ }^{35} \mathrm{CIN}_{7} \mathrm{KO}_{3}[\mathrm{M}+\mathrm{K}]^{+}$ 526.07912, found: 526.0801 .

\section{$\mathrm{N}$-(3-Chlorophenyl)-8-((1-(2,6-dichlorobenzyl)-1H-1,2,3-triazol-4-yl)methoxy)quinazolin-2-amine (7j)}

Reaction of compounds 5 (50 mg, $0.16 \mathrm{mmol})$ with $\mathbf{6 j}(32.5 \mathrm{mg}, 0.16 \mathrm{mmol})$ gave $7 \mathrm{j}: 58.7 \mathrm{mg}, 72 \%$ yield; ${ }^{1} \mathrm{H} \mathrm{NMR}\left(400 \mathrm{MHz}, \mathrm{DMSO}-\mathrm{d}_{6}, \delta \mathrm{ppm}\right): 10.12$ (br s, 1H), 9.32 (s, 1H), 8.39 (ddd after improving the resolution, $J=2.7,1.4,0.6 \mathrm{~Hz}, 1 \mathrm{H}$ ), $8.31(\mathrm{~s}, 1 \mathrm{H}), 7.76(\mathrm{ddd}, J=8.4,2.0,0.9 \mathrm{~Hz}, 1 \mathrm{H}), 7.60-7.56$ ( $\mathrm{m}$ which be approximately analyzed as a dd at $7.58 \mathrm{ppm}$ after improving the resolution, $J=8.1,0.7 \mathrm{~Hz}, 2 \mathrm{H}), 7.54(\mathrm{dd}, J=8.1,1.1 \mathrm{~Hz}, 1 \mathrm{H}), 7.51(\mathrm{dd}, J$ $=7.9,1.3 \mathrm{~Hz}, 1 \mathrm{H}), 7.48(\mathrm{dd}, J=8.9,7.2 \mathrm{~Hz}, 1 \mathrm{H}), 7.35(\mathrm{t}, J=7.9 \mathrm{~Hz}, 1 \mathrm{H}), 7.20(\mathrm{t}, J=8.1 \mathrm{~Hz}, 1 \mathrm{H}), 6.95(\mathrm{ddd}, J=7.9,2.1,0.9 \mathrm{~Hz}, 1 \mathrm{H}), 5.83(\mathrm{~s}, 2 \mathrm{H}), 5.33$ (s, 2H); ${ }^{13} \mathrm{C}$ NMR (75 MHz, DMSO-d 6 , $\delta$ ppm): 161.94, 155.82, 151.56, 142.46, 142.34, 142.06, 135.84, 133.00, 131.59, 130.19, 129.73, 128.90 (x 2), 124.94, 123.71, 121.10, 120.54, 119.68, 117.57, 116.63, 115.10, 61.83, 48.54; LC-MS: 511.3 [M+H]; HRMS (ESI, $\left.\mathrm{CH}_{3} \mathrm{OH}_{2} \mathrm{CH}_{2} \mathrm{Cl}_{2}=9: 1\right) \mathrm{m} / \mathrm{z} \mathrm{calcd}$ for $\mathrm{C}_{24} \mathrm{H}_{17}{ }^{35} \mathrm{Cl}_{3} \mathrm{~N}_{6} \mathrm{NaO}[\mathrm{M}+\mathrm{Na}]^{+}: 533.04216$, found: 533.0427 , calcd for $\mathrm{C}_{24} \mathrm{H}_{18}{ }^{35} \mathrm{Cl}_{3} \mathrm{~N}_{6} \mathrm{O}[\mathrm{M}+\mathrm{H}]^{+}: 511.06022$, found: 511.0601, calcd for $\mathrm{C}_{24} \mathrm{H}_{17}{ }^{35} \mathrm{Cl}_{3} \mathrm{~N}_{6} \mathrm{KO}$ 
$[\mathrm{M}+\mathrm{K}]^{+}: 549.01610$, found: 549.0170 .

8-((1-Benzyl-1H-1,2,3-triazol-4-yl)methoxy)-N-(3-chlorophenyl)quinazolin-2-amine (7k)

Reaction of compounds $5(50 \mathrm{mg}, 0.16 \mathrm{mmol})$ with $\mathbf{6 k}(21.3 \mathrm{mg}, 0.16 \mathrm{mmol})$ gave $7 \mathbf{k}: 49.5 \mathrm{mg}, 70 \%$ yield; ${ }^{1} \mathrm{H} \mathrm{NMR}\left(300 \mathrm{MHz}, \mathrm{DMSO}-\mathrm{d}_{6}, \delta \mathrm{ppm}\right): 10.10$ (br s, 1H), $9.32(\mathrm{~s}, 1 \mathrm{H}), 8.34(\mathrm{~s}, 1 \mathrm{H}), 8.33(\mathrm{t}, J=2.0 \mathrm{~Hz}, 1 \mathrm{H}), 7.82$ (ddd, $J=8.3,2.1,0.9 \mathrm{~Hz}, 1 \mathrm{H}), 7.54(\mathrm{dd}, J=8.1,1.1 \mathrm{~Hz}, 1 \mathrm{H}), 7.51(\mathrm{dd}, J=7.9,1.1$ $\mathrm{Hz}, 1 \mathrm{H}), 7.42-7.30(\mathrm{~m}, 6 \mathrm{H}), 7.15(\mathrm{t}, J=8.1 \mathrm{~Hz}, 1 \mathrm{H}), 6.94$ (ddd, $J=7.9,2.1,0.9 \mathrm{~Hz}, 1 \mathrm{H}), 5.64(\mathrm{~s}, 2 \mathrm{H}), 5.35(\mathrm{~s}, 2 \mathrm{H}) ;{ }^{13} \mathrm{C} \mathrm{NMR}\left(75 \mathrm{MHz}, \mathrm{DMSO}-\mathrm{d}_{6}, \delta\right.$ ppm): 161.94, 155.82, 151.55, 142.81, 142.47, 142.06, 135.86, 132.95, 129.77, 128.67 (x 2), 128.08, 127.83 (x 2), 124.70, 123.71, 121.12, 120.57,

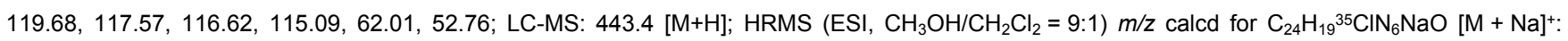
465.12011, found: 465.1206 , calcd for $\mathrm{C}_{24} \mathrm{H}_{19}{ }^{35} \mathrm{CIN}_{6} \mathrm{KO}[\mathrm{M}+\mathrm{K}]^{+}: 481.09405$, found: 481.0951 .

N-(3-Chlorophenyl)-8-((1-(4-methyl-3-nitrophenyl)-1H-1,2,3-triazol-4-yl)methoxy)quinazolin-2-amine (7I)

Reaction of compounds $5(25 \mathrm{mg}, 0.08 \mathrm{mmol})$ with $6 \mathrm{l}(20.2 \mathrm{mg}, 0.16 \mathrm{mmol})$ gave $7 \mathrm{l}: 50.7 \mathrm{mg}, 52 \%$ yield; ${ }^{1} \mathrm{H} \mathrm{NMR}\left(400 \mathrm{MHz}, \mathrm{CDCl}_{3}\right): \delta 9.12(\mathrm{br} \mathrm{s}, 1 \mathrm{H})$, $8.42(\mathrm{~s}, 1 \mathrm{H}$ ), $8.38(\mathrm{~s}, 2 \mathrm{H}), 7.95(\mathrm{dd}, J=8.4,1.8 \mathrm{~Hz}, 1 \mathrm{H}$ ), $7.53(\mathrm{br} \mathrm{d}, J=8.3 \mathrm{~Hz}, 1 \mathrm{H}$ ), 7.47 (envelope (up to $7.50 \mathrm{ppm}$ and overlapped at higher field), $1 \mathrm{H}), 7.46-7.29(\mathrm{~m}, 4 \mathrm{H}: 2 \mathrm{H}$ at 7.46-7.37 ppm and $2 \mathrm{H}$ at 7.37-7.29 ppm), $7.21(\mathrm{t}, \mathrm{J}=8.0 \mathrm{~Hz}, 1 \mathrm{H}), 6.95(\mathrm{br} \mathrm{d}, J=7.8 \mathrm{~Hz}, 1 \mathrm{H}), 5.57(\mathrm{~s}, 2 \mathrm{H}), 2.70(\mathrm{~s}, 3 \mathrm{H})$; ${ }^{13} \mathrm{C}$ NMR $\left(100 \mathrm{MHz}, \mathrm{CDCl}_{3}\right): \delta 161.92,155.97,155.12,152.02,149.44,145.51,143.43,140.89,135.57,134.54,134.29,134.11,129.77,124.53$, $124.15,122.24,121.08,120.25,118.53,116.79,116.65,115.37,63.50,20.31$; LC-MS: $488.2[\mathrm{M}+\mathrm{H}]$.

\section{Kinase assays}

For mammalian kinases, the activities were evaluated using the ADP-Glo ${ }^{\mathrm{TM}}$ assay kit according to the manufacturer instructions (Promega, Madison, WI). Detailed procedure was previously reported. ${ }^{50}$ Activities were expressed in \% of maximal activity measured with dimethyl sulfoxide (DMSO) diluted at $1 \%$. Each point was measured in duplicate. $I_{50}$ values were determined from dose response curves using Prism-GraphPad (GraphPad Software, San Diego, CA, USA). The DNA vector used for the expression of DYRK1 kinase (from Rattus norvegicus, amino acids 1 to 499 including the kinase domain) was kindly provided by Dr. W. Becker, Aachen, Germany.

For human kinases, the activities were established by the Eurofins company, with a protocol reported on their web site.

\section{Molecular docking}

The X-ray crystal structures of CLK isoforms (1 to 4 with PDB: 5X8I, 6FYL, 2WU6 \& 6FYV) with resolution of less than $2.5 \AA$ were retrieved from PDB and employed as templates for the DB-18 binding studies. The receptor grid around imperative sites of co-crystal ligands positioned at ATP-binding pocket of CLK's was generated with Glide module of Schrodinger's LLC. The extra precision docking mode was used both for classical docking (Glide) and Induced-fit docking.

\section{Molecular dynamics}

The Desmond system and OPLS_2005 force field were used for molecular dynamics experiment (D.E. Shaw Research. ${ }^{51}$ Briefly, the protein complex was soaked with the SPC model of water and $0.15 \mathrm{M} \mathrm{Na}^{+}$. The solvent was first optimized through energy minimization, keeping protein-ligand complex frozen. Constraints were then released for molecular dynamics, under NPT condition (NHC thermostat at 1 atm pressure, $\mathrm{T}=300 \mathrm{~K}$ ) and default parameters. The production run was carried out for $500 \mathrm{~ns}$ per complex system with trajectory sampling every $2 \mathrm{~ns}$.

\section{Protocole ImPACell for cytotoxicity studies:}

\section{Cell culture}

Skin normal fibroblastic cells are purchased from Lonza (Basel, Switzerland), HuH7, Caco-2, MDA-MB-231, HCT116, PC3, MCF7 and NCI-H727 cancer cell lines were obtained from the ECACC collection (Porton Down, UK). Cells are grown at $37^{\circ} \mathrm{C}, 5 \% \mathrm{CO} 2$ in ECACC recommended media: DMEM for HuH7, MDA-MB-231 and fibroblast, EMEM for MCF7 and CaCo-2, McCoy's for HCT116 and RPMI for PC3 and NCl-H727. All culture media are supplemented by $10 \%$ of FBS, $1 \%$ of penicillin-streptomycin and $2 \mathrm{mM}$ glutamine.

\section{Cytotoxic assay \\ Primary screen (unique concentration)}

Chemicals are solubilized in DMSO at a concentration of $10 \mathrm{mM}$ (stock solution) and diluted in culture medium to the desired final concentrations. The dose effect cytotoxic assay of chemical is performed at $25 \mu \mathrm{M}$. Cells are plated in 96 wells plates (4000 cells/well). Twenty-four hours after seeding, cells are exposed to chemicals. After $48 \mathrm{~h}$ of treatment, cells are washed in PBS and fixed in cooled $90 \%$ ethanol/5\% acetic acid for 20 minutes and the nuclei are stained with Hoechst 33342 (B2261 Sigma). Image acquisition and analysis are performed using a Cellomics ArrayScan VTI/HCS Reader (ThermoScientific). The survival percentages are calculated as the percentage of cell number after compound treatment over cell number after DMSO treatment.

Secondary screen $\left(\mathrm{IC}_{50}\right)$ 
Positives compounds in the primary screen $\left(30 \%\right.$ of decrease of cell number) are tested for the $\mathrm{IC}_{50}$ determination. The screen is performed by increasing concentrations of each chemical (final well concentrations: $0.1 \mu \mathrm{M}-0.3 \mu \mathrm{M}-0.9 \mu \mathrm{M}-3 \mu \mathrm{M}-9 \mu \mathrm{M}-25 \mu \mathrm{M}$ ). Cells are plated in 96 wells plates (4000 cells/well). Twenty-four hours after seeding, cells are exposed to chemicals. After $48 \mathrm{~h}$ of treatment, cells are washed in PBS and fixed in cooled $90 \%$ ethanol/5\% acetic acid for 20 minutes and the nuclei are stained with Hoechst 33342 (B2261 Sigma). Image acquisition and analysis are performed using a Cellomics ArrayScan VTI/HCS Reader (ThermoScientific). The survival percentages are calculated as the percentage of cell number after compound treatment over cell number after DMSO treatment. The relative $\mathrm{IC}_{50}$ are calculated using the curve fitting XLfit 5.5 .0 .5 (idbs) integrated in Microsoft Excel as an add on. The 4 Parameter Logistic Model or Sigmoidal Dose-Response Model is used $\left(f i t=\left(A+\left((B-A) /\left(1+\left((C / x)^{\wedge} D\right)\right)\right)\right)\right.$.

\section{Declaration of Competing Interest}

The authors declare no conflict of interest.

\section{Acknowledgements}

We thank Chemveda Life Sciences for providing laboratory facility for carrying these research experiments. This research has been performed also as part of the Indo-French "Joint Laboratory for Natural Products and Synthesis towards Affordable Health". We thank CSIR, CNRS and University of Rennes 1 for their support. We thank CRMPO (University of Rennes 1) for the mass spectra analysis. We thank European FEDER founds for acquisition of D8Ventur X-ray diffractometer used for crystal structure determination. We thank Dr F. Justaud for his help to obtain crystals of $\mathbf{7 h}$ suitable for X-Ray analysis. The authors thank the Canceropole Grand Ouest (axis: natural sea products in cancer treatment), IBiSA (French Infrastructures en sciences du vivant: biologie, santé et agronomie) and Biogenouest (Western France life science and environment core facility network) for supporting the KISSf screening facility (FR2424, CNRS and Sorbonne Université), Roscoff, France. We thank Osmania University for the financial assistance under UGCUPE FAR, SAP, OU-DST PURSE-II Programme, sanction letter no. C-DST-PURSE-II/15/2019.

\section{Appendice A; Supplementary Materiel}

Supplementary data to this article (Cytotoxicity studies of quinazolines 7: Supplementary Table 1; dose-dependent effect of DB18 on rat and human DYRKs (Supplementary Figure 1) Molecular modelling: Supplementary Figures 2 to 7; Complete experimental procedures and characterisation for new compounds, with copies of the ${ }^{1} \mathrm{H}$ and ${ }^{13} \mathrm{C} N \mathrm{NR}$ spectra) can be found online at: https://doi........

\section{References}

1 Knapp S, New opportunities for kinase drug repurposing and target discovery. Br. J. Cancer, 2018;118:936-937.

2 (a) Ferguson FM, Gray NS, Kinase inhibitors: the road ahead. Nature Reviews Drug Discovery 2018;17:353-377; (b) Laufer S, Briner K, Bajorath J, Georg GI, Wang S, New horizons in drug discovery-understanding and advancing kinase inhibitors. J. Med. Chem. 2020;63:7921-7922.

3 Carles F, Bourg S, Meyer C, Bonnet P, PKIDB: A curated, annotated and updated database of protein kinase inhibitors in clinical trials. Molecules, 2018;23:908.

4 Roskoski Jr R, Properties of FDA-approved small molecule protein kinase inhibitors. Pharmacol. Res, 2019;144:19-50.

5 Havens MA, Duelli DM, Hastings ML, Targeting RNA splicing for disease therapy. Wiley Interdiscip Rev RNA, 2013;4:247-266

6 Faustino NA, Cooper TA, Pre-mRNA splicing and human disease. Genes Dev., 2003;17:419-437.

7 Cooper TA, Wan L, Dreyfuss G, RNA and disease. Cell, 2009;136:777-793.

8 Oltean S, Bates DO, Hallmarks of alternative splicing in cancer. Oncogene, 2014;33:5311-5318.

9 Wahl MC, Will CL, Luhrmann R, The spliceosome: design principles of a dynamic RNP machine. Cell, 2009;136:701-718. 
10 Bourgeois CF, Lejeune F, Stevenin J, Broad specificity of SR (serine/arginine) proteins in the regulation of alternative splicing of pre-messenger RNA. Prog. Nucleic Acid Res. Mol. Biol., 2004;78:37-88.

11 Colwill K, Pawson T, Andrews B, Prasad J, Manley JL, Bell JC, Duncan PI, The Clk/Sty protein kinase phosphorylates SR splicing factors and regulates their intranuclear distribution. EMBO J., 1996;15:265-275.

12 Gui JF, Lane WS, Fu XD, A serine kinase regulates intracellular localization of splicing factors in the cell cycle. Nature, 1994;369;678-682.

13 Giannakouros T, Nikolakaki E, Mylonis I, Georgatsou E, Serine-arginine protein kinases: a small protein kinase family with a large cellular presence. FEBS J., (2011;278:570-586.

14 Schneider M, Hsiao HH, Will CL, Giet R, Urlaub H, Luhrmann R, Human PRP4 kinase is required for stable tri-snRNP association during spliceosomal B complex formation. Nat. Struct. Mol. Biol., 2010;17:216-221.

15 Rossi F, Labourier E, Forne T, Divita G, Derancourt J, Riou JF, Antoine E, Cathala G, Brunel C, Tazi J, Specific phosphorylation of SR proteins by mammalian DNA topoisomerase I. Nature, 1996;381-80-82

16 Duncan PI, Stojdl DF, Marius RM, Scheit KH, Bell JC, The Clk2 and Clk3 dual-specificity protein kinases regulate the intranuclear distribution of SR proteins and influence pre-mRNA splicing. Exp. Cell Res., 1998;241:300-308.

17 Wang HY, Lin W, Dyck JA, Yeakley JM, Songyang Z, Cantley LC, Fu XD, SRPK2: a differentially expressed SR protein-specific kinase involved in mediating the interaction and localization of pre-mRNA splicing factors in mammalian cells. J. Cell Biol., 1998;140:737-750.

18 Tacke R, Chen Y, Manley JL, Sequence-specific RNA binding by an SR protein requires RS domain phosphorylation: creation of an SRp40-specific splicing enhancer. Proc. Natl. Acad. Sci. USA, 1997;94:1148-1153.

19 Corkery DP, Holly AC, Lahsaee S, Dellaire G, Connecting the speckles: Splicing kinases and their role in tumorigenesis and treatment response. Nucleus, 2015;6:279-288.

20 Nayler O, Stamm S, Ullrich A, Characterization and comparison of four serine- and arginine-rich (SR) protein kinases. Biochem. J., 1997;326(Pt 3):693700 .

21 Ben-David Y, Letwin K, Tannock L, Bernstein A, Pawson T, A mammalian protein kinase with potential for serine/threonine and tyrosine phosphorylation is related to cell cycle regulators. EMBO J., 1991;10:317-325.

22 Muraki M, Ohkawara B, Hosoya T, Onogi H, Koizumi J, Koizumi T, Sumi K, Yomoda J, Murray MV, Kimura H, Furuichi K, Shibuya H, Krainer AR, Suzuki M, Hagiwara M, Manipulation of alternative splicing by a newly developed inhibitor of Clks. J. Biol. Chem., 2004;279:24246-24254

23 Sako Y, Ninomiya K, Okuno Y, Toyomoto M, Nishida A, Koike Y, Ohe K, Kii I, Yoshida S, Hashimoto N, Hosoya T, Matsuo M, Harigawa M, Development of an orally available inhibitor of CLK1 for skipping a mutated dystrophin exon in Duchenne muscular dystrophy. Sci. Rep. 2017;7:46126.

24 Babu N, Pinto SM, Biswas M, Subbannayya T, Rajappa M, Mohan SV, Advani J, Rajagopalan P, Sathe G, Syed N, Radhakrishna VD, Muthusamy O, Navani S, Kumar RV, Gopisetty G, Rajkumar T, Radhakrishnan P, Thiyagarajan S, Pandey A, Gowda H, Mahumber P, Chatterjee A, Phosphoproteomic analysis identifies CLK1 as a novel therapeutic target in gastric cancer. Gastric Cancer. 2020;23:796-810.

25 Iwai K, Yaguchi M, Nishimura K, Yamamoto Y, Tamura T, Nakata D, Dairiki R, Kawakita Y, Mizojiri R, Ito Y, Asano M, Maezaki H, Nakayama Y, Kaishima M, Hayashi K, Teratani M, Miyakawa S, Iwatani M, Miyamoto M, Klein MG, Lane W, Snell G, Tjhen R, He X, Pulukuri S, Nomura T, Anti-tumor efficacy of a novel CLK inhibitor via targeting RNA splicing and MYC-dependent vulnerability. EMBO Mol. Med. 2018;10(6):e8289.

26 Riggs JR, Nagy M, Elsner J, Erdman JP, Cashion D, Robinson D, Harris R, Huang D, Tehrani L, Deyanat-Yazdi G, Narla RK, Peng X, Tran T, Barnes L, Miller T, Katz J, Tang Y, Chen M, Moghaddam MF, Bahmanyar S, Pagarigan B, Delker S, Lebrun L, Chamberlain PP, Calabrese A, Cana SS, Leftheris K, Zhu D, Boylan J F, The Discovery of a Dual TTK Protein Kinase/CDC2-Like Kinase (CLK2) Inhibitor for the Treatment of Triple Negative Breast Cancer Initiated from a Phenotypic Screen. J. Med. Chem. 2017;60:8989-9002.

27 Tam BY, Chiu K, Chung H, Bossard C, Nguyen JD, Creger E, Eastman BW, Mak CC, Ibanez M, Ghias A, Cahiwat J, Do L, Cho S, Nguyen J, Deshmukh V, Stewart J, Chen C-W, Barroga C, Dellamary L, Kc SK, Phallen TJ, Hood J, Cha S, Yazici Y, The CLK inhibitor SM08502 induces anti-tumor activity and reduces Wnt pathway gene expression in gastrointestinal cancer models. Cancer Lett. 2020;473:186-197.

28 Fedorov O, Huber K, Eisenreich A, Filippakopoulos P, King O, Bullock AN, Szklarczyk D, Jensen LJ, Fabbro D, Trappe J, Rauch U, Bracher F, Knapp S, Specific CLK inhibitors from a novel chemotype for regulation of alternative splicing. Chem. Biol. 2011;18:67-76.

29 Coombs TC, Tanega C, Shen M, Wang JL, Auld DS, Gerritz SW, Schoenen FJ, Thomas CJ, Aube J, Small-molecule pyrimidine inhibitors of the cdc2-like (Clk) and dual specificity tyrosine phosphorylation-regulated (Dyrk) kinases: development of chemical probe ML315. Bioorg. Med. Chem. Lett. 2013;23:36543661 .

30 Grabher P, Durieu E, Kouloura E, Halabalaki M, Skaltsounis LA, Meijer L, Hamburger M, Potterat O, Library-based discovery of DYRK1A/CLK1 inhibitors from natural product extracts. Planta Med. 2012;78:951-956.

31 Rosenthal AS, Tanega C, Shen M, Mott BT, Bougie JM, Nguyen DT, Misteli T, Auld DS, Maloney DJ, Thomas CJ, Potent and selective small molecule inhibitors of specific isoforms of Cdc2-like kinases (Clk) and dual specificity tyrosine-phosphorylation-regulated kinases (Dyrk). Bioorg. Med. Chem. Lett. 
32 Tazarki H, Zeinyeh W, Esvan YJ, Knapp S, Chatterjee D, Schroder M, Joerger AC, Khiari J, Josselin B, Baratte B, Bach S, Ruchaud S, Anizon F, Giraud F, Moreau P, New pyrido[3,4-g]quinazoline derivatives as CLK1 and DYRK1A inhibitors: synthesis, biological evaluation and binding mode analysis. Eur. J. Med. Chem. 2019;166:304-317.

33 Sun Q-Z, Lin G-F, Li L-L, Jin X-T, Huang L-Y, Zhang G, Yang W, Chen K, Xiang R, Chen C, Wei Y-Q, Lu G-W, Yang S-Y, Discovery of potent and selective inhibitors of Cdc2-Like Kinase 1 (CLK1) as a new class of autophagy inducers. J. Med. Chem. 2017; 60:6337-6352.

34 Nemec V, Hylsova M, Maier L, Flegel J, Sievers S, Ziegler S, Schröder M, Berger B-T, Chaikuad A, Valcikkova B, Uldrijan S, Drapela S, Soucek K, Waldmann H, Knapp S, Paruch K Furo[3,2-b]pyridine: A privileged scaffold for highly selective kinase inhibitors and effective modulators of the Hedgehog pathway. Angew. Chem. Int. Ed. 2019;58:1062-1066.

35 Marzaro G, Guiotto A, Chilin A, Quinazoline derivatives as potential anticancer agents: a patent review (2007 - 2010). Expert Opin. Ther. Pat. 2012; 22(3):223-252.

36 Das D., Hong J., Recent advancements of 4-aminoquinazoline derivatives as kinase inhibitors and their applications in medicinal chemistry. Eur. J. Med. Chem. 2019;170:55-72.

37 (a) Sasse K, A simple new method for preparation of 2-substituted quinazolines. Synthesis, 1978;5:379-382; (b) Henriksen ST, Sørensen US, 2Chloroquinazoline, Synthesis and reactivity of a versatile heterocyclic building block. Tetrahedron Lett. 2006;47:8251-8254; (c) Saari R, Törmä J-C, Nevalainen T, Microwave-assisted synthesis of quinoline, isoquinoline, quinoxaline and quinazoline derivatives as CB2 receptor agonists. Bioorg. \& Med. Chem. 2011:19:939-950; (d) Charaschanya M, Bogdan AR, Wang Y, Djuric SW, Nucleophilic aromatic substitution of heterocycles using a high-temperature and high-pressure flow reactor. Tetrahedron Lett. 2016;57:1035-1039; (e) Leitch JA, McMullin CL, Paterson AJ, Mahon MF, Bhonoah Y, Frost CG, Ruthenium-Catalyzed para-Selective C-H Alkylation of Aniline Derivatives. Angew. Chem. Int. Ed. 2017;56:15131 -15135; (f) Monastyrskyi A, Bayle S, Quereda V, Grant W, Cameron M, Duckett D, Roush W, Discovery of 2-arylquinazoline derivatives as a new class of ASK1 inhibitors. Bioorg. \& Med. Chem. Lett. 2018;28:400-404

38 Brahmaiah D, Durga Bhavani AK, Aparna P, Sampath Kumar N, Solhi H, Le Guevel R, Baratte B, Ruchaud S, Bach S, Mosset P, Grée R, Synthesis and biological studies of new quinazolines with ether functions in position 2. Arkivoc 2019;5:96-107.

39 (a) Kumar V Mohan C Gupta M Mahajan MP A catalyst- and solvent-free selective approach to biologically important quinazolines and benzo[g]quinazoline. Tetrahedron 2005;61:3533-3538; (b) Xuhu H, Haijun J, Hua F, Renzhong Q, Yufen Z, Synthesis, 2009;16:2679-2688; (c) Wang Y, Wang $\mathrm{H}$, Peng J, Zhu Q, Palladium-catalyzed intramolecular $\mathrm{C}\left(\mathrm{sp}^{2}\right)-\mathrm{H}$ amidination by isonitrile insertion provides direct access to 4-aminoquinazolines from $\mathrm{N}$ arylamidines. Org. Lett. 2011;13:4604-4607; (d) Quang Tran L, Li J, Neuville L, Copper-catalyzed domino three-component approach for the assembly of 2-aminated benzimidazoles and quinazolines. J. Org. Chem. 2015;80:6102-6108; (e) Liang E, Wu Y, Chen J, Xiong W, Zhao J, Yao X, Tang X, Coppercatalyzed aerobic oxidative cyclization protocol for the synthesis of quinazolines via amination of $\mathrm{C}\left(\mathrm{sp}^{3}\right)-\mathrm{H}$ bonds of methylazaarenes. Tetrahedron 2019;75:130783; (f) Jatangi N, Palakodety RK, Base-catalyzed synthesis of quinazolines in aqueous medium. Tetrahedron Lett. 2019;60:151186; (g) Le-NhatThuy G, Nguyen Thi N, Pham-The H, Dang Thi TA, Nguyen Thi H, Nguyen Thi TH, Nguyen Hoang S, Van Nguyen T. Synthesis and biological evaluation of novel quinazoline-triazole hybrid compounds with potential use in Alzheimer's disease. Bioorg. \& Med.Chem. Lett. 2020;30:127404.

40 For selected reviews on click chemistry see: (a) Kolb HC, Finn M G, Sharpless KB, Click chemistry: diverse chemical function from a few good reactions. Ang. Chem. Int. Ed. 2001;40:2004-2021; (b) Rostovtsev VV, Green LG, Sharpless KB, A stepwise Huisgen cycloaddition process: copper(I)-catalyzed regioselective "ligation" of azides and terminal alkynes. Ang. Chem. Int. Ed. 2002;41:2596-2599; (c) Tornoe CW, Christensen C, Medal M, Peptidotriazoles on solid phase: $[1,2,3]$ triazoles by regiospecific copper (I) cycloadditions of terminal alkynes to azides. J. Org. Chem. 2002;67:3057-3064; (d) Lutz J-F, Copperfree azide-alkyne cycloadditions: new insights and perspectives. Ang. Chem. Int. Ed. 2008;47:2182-2184.

41 CCDC 2007740 (for compound 7h), contain the supplementary crystallographical data for this paper. These data can be obtained free of charge from the Cambridge Crystallographic Data Centre (CCDC), 12 Union Road, Cambridge CB2 1EZ, UK; fax, +44(0) 1223 336 033; e-mail: deposit@ccdc.cam.ac.uk 42 Esvan YJ, Zeinyeh W, Boibessot T, Nauton L, Thery V, Knapp S, Chaikuad A, Loaec N, Meijer L, Anizon F, Giraud F, Moreau P, Discovery of pyrido[3,4g]quinazoline derivatives as CMGC family protein kinase inhibitors: Design, synthesis, inhibitory potency and X-ray co-crystal structure. Eur. J. Med. Chem. 2016:118:170-177.

43 Zhijian X, Zhuo Y, Yingtao L, Yunxiang L, Kaixian C, Weiliang Z, Halogen Bond: Its Role beyond Drug-Target Binding Affinity for Drug Discovery and Development. J. Chem. Inf. \& Mod. 2014;54:69-78.

44 Shinada NK, de Brevern AG, Schmidtke P, Halogens in Protein-Ligand Binding Mechanism: A Structural Perspective. J. Med. Chem. 2019;62:9341-9356. 45 Heroven C, Georgi V, Ganotra GK, Brennan P, Wolfreys F, Wade RC, Fernández-Montalván AE, Chaikuad A, Knapp S. Halogen-Aromatic m Interactions Modulate Inhibitor Residence Times. Angew. Chem. Int. Ed. 2018;57:7220-7224.

46 a) Muraki M, Ohkawara B, Hosoya T, Onogi H, Koizumi J, Koizumi T, Sumi K, Yomoda J, Murray MV, Kimura H, Furuichi K, Shibuya H, Krainer AR, Suzuki M, Hagiwara M, Manipulation of alternative splicing by a newly developed inhibitor of Clks. J. Biol. Chem. 2004;279:24246-54; b) Lawson M, Rodrigo J, Baratte B, Robert T, Delehouzé C, Lozach O, Ruchaud S, Bach S, Brion JD, Alami M, Hamze A, Synthesis, biological evaluation and molecular modeling studies of imidazo[1,2-a]pyridines derivatives as protein kinase inhibitors. Eur. J. Med. Chem. 2016;123:105-114.

47 Schröder M, Bullock AN, Fedorov O, Bracher F, Chaikuad A, Knapp S, DFG-1 Residue Controls Inhibitor Binding Mode and Affinity,Providing a Basis for Rational Design of Kinase Inhibitor Selectivity. J.Med.Chem.2020; 63:10224-10234.

48 Bullock AN, Das S, Debreczeni JE, Rellos P, Fedorov O, Niesen FH, Guo K, Papagrigoriou E, Amos AL, Cho S, Turk BE, Ghosh G, Knapp S, Kinase domain insertions define distinct roles of CLK kinases in SR protein phosphorylation. Structure 2009;17:352-62. 49 Lapenna S, Giordano A, Cell cycle kinases as therapeutic targets for cancer. Nat Rev Drug Discov 2009;8:547-566.

50 Ibrahim N, Bonnet P, Brion JD, Peyrat JF, Bignon J, Levaique H, Josselin B, Robert T, Colas P, Bach S, Messaoudi S, Alami M, Hamze A, Identification of a new series of Flavopiridol-like structures as kinase inhibitors with high cytotoxic potency. Eur. J. Med. Chem. 2020;199:112355.

51 Desmond molecular dynamics system, D. E. Shaw research, New York, NY, 2019. Interperability tools, Schrodinger, New York, NY, 2019. (https://www.schrodinger.com/desmond). 


\section{Graphical Abstract}
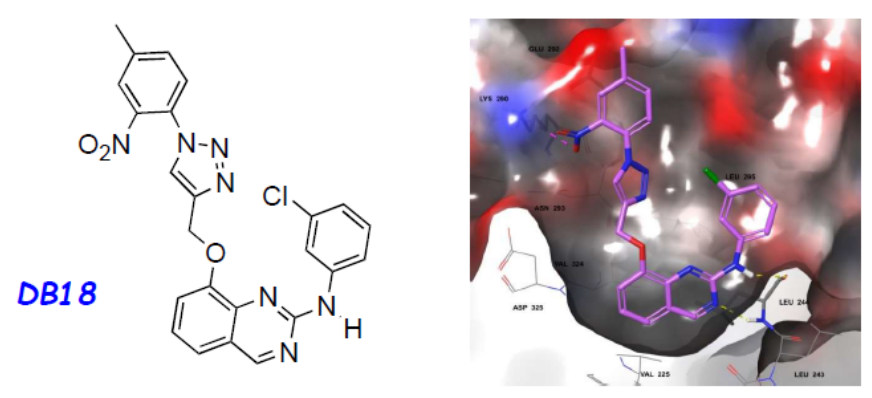

* potent inhibitor of HsCLK-1, -2 and -4 kinases with IC $C_{50}$ from 11 to $27 \mathrm{~nm}$

* no activity on HsDYRK1A, 1B and HsDYRK2 kinases at $100 \mu \mathrm{M}$ 


\section{Declaration of interests}

$\bigotimes$ The authors declare that they have no known competing financial interests or personal relationships that could have appeared to influence the work reported in this paper.

$\square$ The authors declare the following financial interests/personal relationships which may be considered as potential competing interests: 